Ulil norden

Nordiske arbeidstilsyn med utenlandsk arbeidskraft i bygg og transport

\title{
|VIII
}
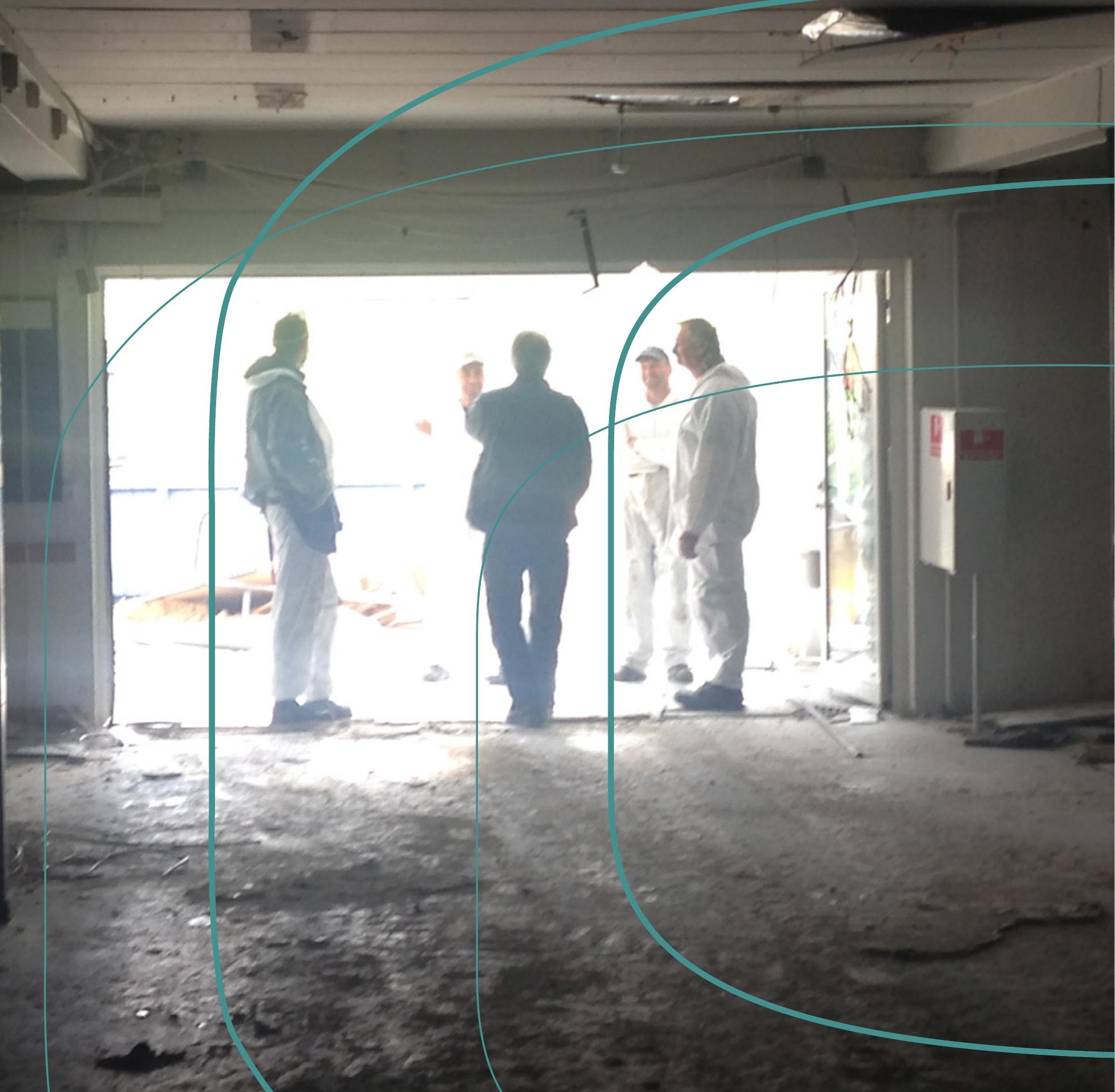





\section{Nordiske arbeidstilsyn med utenlandsk arbeidskraft i bygg og transport}

Anne Mette Ødegård og Line Eldring

TemaNord 2016:530 
Nordiske arbeidstilsyn med utenlandsk arbeidskraft i bygg og transport

Anne Mette Ødegård og Line Eldring

ISBN 978-92-893-4616-0 (PRINT)

ISBN 978-92-893-4617-7 (PDF)

ISBN 978-92-893-4618-4 (EPUB)

http://dx.doi.org/10.6027/TN2016-530

TemaNord 2016:530

ISSN 0908-6692

(c) Nordisk ministerråd 2016

Layout: Hanne Lebech

Omslagsfoto: Line Eldring (Fafo Institutt for arbeidslivs- og velferdsforskning)

Trykk: Rosendahls-Schultz Grafisk

Opplag: 100

Printed in Denmark

Denne rapporten er gitt ut med finansiell støtte fra Nordisk ministerråd. Innholdet i rapporten avspeiler imidlertid ikke nødvendigvis Nordisk ministerråds synspunkter, holdninger eller anbefalinger.

\section{www.norden.org/nordpub}

\section{Det nordiske samarbeidet}

Det nordiske samarbeidet er en av verdens mest omfattende regionale samarbeidsformer. Samarbeidet omfatter Danmark, Finland, Island, Norge og Sverige samt Færøyene, Grønland og Åland.

Det nordiske samarbeidet er både politisk, økonomisk og kulturelt forankret, og er en viktig med-spiller i det europeiske og internasjonale samarbeid. Det nordiske fellesskapet arbeider for et sterkt Norden i et sterkt Europa.

Det nordiske samarbeidet ønsker å styrke nordiske og regionale interesser og verdier i en global omverden. Felles verdier landene imellom bidrar til å styrke Nordens posisjon som en av verdens mest innovative og konkurransekraftige regioner.

\section{Nordisk ministerråd}

Ved Stranden 18

DK-1061 København K

Telefon (+45) 33960200

\section{www.norden.org}




\section{Innhold}

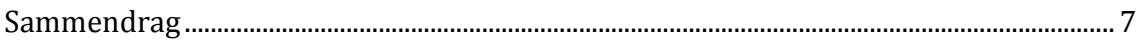

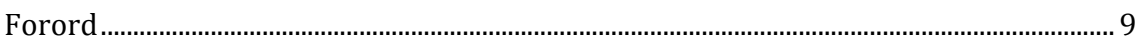

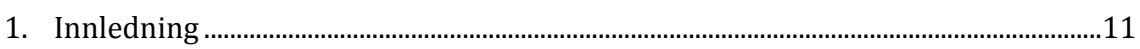

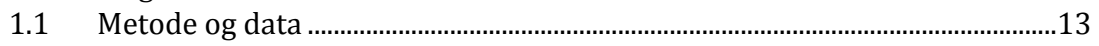

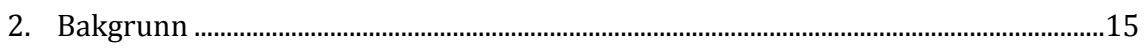

2.1 Ulike sjekkpunkter .............................................................................................15

2.2 Allmenngjøring av tariffavtaler ..................................................................16

$2.3 \quad$ Nye utfordringer - nye tiltak .............................................................................16

2.4 Utstasjonering og håndhevelse...............................................................................18

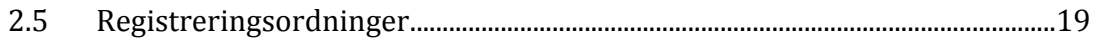

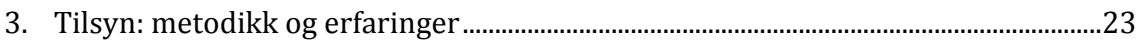

3.1 Hva slags oversikt har arbeidstilsynene over utenlandske bedrifter/arbeidstakere? ....................................................................................2

3.2 Organisering og gjennomføring av tilsynsvirksomheten ...............................26

3.3 Hva kontrolleres? .............................................................................................

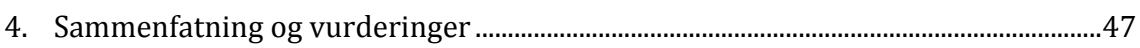

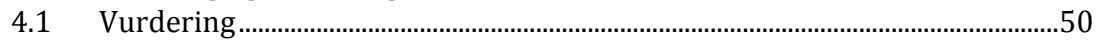

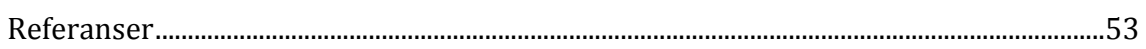

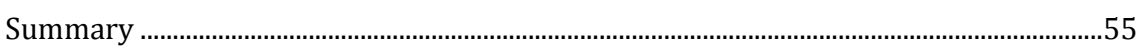





\section{Sammendrag}

Østutvidelsene av EU fjernet grensene mellom nasjonale arbeidsmarkeder med svært ulike nivåer i arbeids- og levekår. Dette har ført til økt mobilitet av arbeidskraft fra øst til vest i Europa. Mange østeuropeiske arbeidstakere og bedrifter har funnet veien til de nordiske landene, og etablerte standarder i disse arbeidsmarkedene er satt under press. I dette prosjektet har vi studert hvordan arbeidstilsynene i Danmark, Norge og Sverige gjennomfører kontroll, tilsyn og veiledning av utenlandske virksomheter og arbeidstakere innenfor bygge- og transportnæringene. Selv om mange av utfordringene er felles, er det store variasjoner mellom landene når det gjelder hvilke tiltak og reguleringer som er iverksatt. Studien viser at det også er forskjeller i hvordan tilsynsarbeidet organiseres, hva slags registreringsordninger som brukes, hva som kontrolleres og hvilken teknologi som er tilgjengelig for tilsynsinspektørene. 



\section{Forord}

I alle de nordiske landene har den økte europeiske arbeids- og tjenestemobiliteten gitt arbeidstilsynene nye og store utfordringer. Selv om det varierer noe hvilke roller arbeidstilsynene har, står de overfor en rekke parallelle utfordringer når det gjelder tilsynet med utenlandske bedrifter og arbeidstakere. En av hovedkonklusjonene i prosjektet "Arbeidstilsynenes roller, strategier og redskaper i arbeidet mot sosial dumping: En nordisk pilotstudie"1 ${ }^{1}$ var at det er behov for mer kunnskap om den konkrete innretningen av ulike ordninger, reguleringer og tilsynsmetoder rettet mot denne typen virksomheter - samt virkninger av disse. Selv om utfordringene er sammenlignbare, og det er mange likheter i det overordnede regelverket, er det store variasjoner i hvordan disse utfordringene håndteres $\mathrm{i}$ den praktiske tilsynsvirksomheten. I dette prosjektet ønsket vi derfor å utforske dette temaet videre i tre av de nordiske landene, nærmere bestemt i Danmark, Norge og Sverige.

Prosjektet har blitt gjennomført i et samarbeid mellom forskere fra Fafo Institutt for arbeids- og velferdsforskning i Oslo og arbeidstilsynene i Danmark (Arbejdstilsynet), Norge (Arbeidstilsynet) og Sverige (Arbetsmiljöverket). Representanter fra arbeidstilsynene har deltatt $\mathrm{i}$ workshoper underveis, lagt til rette for forskernes feltarbeid og bidratt med informasjon og data. Deres hjelp har vært til uvurderlig nytte, og vi vil rette en stor takk til Erik Bjernemose (DK), Berit Bøe (NO), Dorte Harning (DK), Simen Husby (NO), Kicki Höök (SE), Barbro Köhler Krantz (SE), Morten Lien (NO), Preben Rasmussen (DK), Gabriel Sanz (SE) og Anne Sørum (NO) for godt og inspirerende samarbeid. Tusen takk også til alle inspektører og andre informanter som stilte opp under feltarbeidet i de ulike landene. 
Vi vil videre takke Nordisk Ministerråds Arbeidsmiljøutvalg for støtten til prosjektet, og utvalgssekretær Sven Nielsen for oppfølgingen underveis. Representantene fra arbeidstilsynene har gitt svært gode innspill og kommentarer til tidligere rapportutkast. Det endelige resultatet og konklusjonene - samt eventuelle feil og mangler - er det imidlertid undertegnede som har ansvaret for.

Line Eldring og Anne Mette Ødegård, Fafo

Oslo, juni 2016 


\section{Innledning}

Østutvidelsene 2 av EU i 2004 og 2007 fjernet grensene mellom nasjonale arbeidsmarkeder med svært ulike nivåer i arbeids- og levekår. Dette ble startskuddet for den største forflytningen av arbeidskraft Europa har sett i nyere tid. Svært mange mobile arbeidstakere har også funnet veien til de nordiske landene, som gjennom den siste tiårsperioden har opplevd en sterk internasjonalisering av arbeidsmarkedene. Den store tilstrømningen av arbeidsinnvandrere og utstasjonerte arbeidstakere har satt etablerte standarder under press, og svakheter i regulerings- og kontrollregimene har kommet klarere til syne enn tidligere. Dette dreier seg særlig om i hvilken grad utenlandske arbeidstakere sikres anstendige og likeverdige betingelser når det gjelder lønn og arbeidstid, helse, miljø og sikkerhet (HMS) og boligforhold.

De nordiske landene har noen distinkte særtrekk som gjerne sammenfattes med begrepet "den nordiske modellen". Landene har viktige fellestrekk i verdier og institusjoner, samt høy sysselsetting, generøse velferdsordninger og høy grad av likhet i arbeids- og levekår. Viktige stikkord er et organisert arbeidsliv bygd på samspillet mellom lov- og avtaleregulering, samarbeid mellom arbeidslivets parter, en koordinert lønnsdannelse og universelle velferdsordninger (Dølvik et al. 2014).

I alle de nordiske landene spiller arbeidstilsynene en sentral, men noe varierende rolle når det gjelder å sikre utenlandske arbeidstakere anstendige vilkår i arbeidsmarkedet. Ulikhetene gjenspeiler nasjonale forskjeller når det gjelder arbeidstilsynenes mandater, strategier og virkemidler - både generelt og når det gjelder spesielle tiltak mot sosial dumping som er iverksatt i kjølvannet av EU-utvidelsene (Eldring et al. 2013:10). Internasjonaliseringen av arbeidsmarkedene har medført at arbeidstilsynene har fått større utfordringer, både på grunn av økte problemer i en del bransjer og fordi tilsynene til dels har fått nye oppgaver og ansvarsområder. I hele Norden er det iverksatt eller er under iverksetting ulike tiltak, prosjekter, strategier og metoder for å styrke tilsynet på dette feltet, og det er i varierende grad tilført ekstra ressurser til arbeidet.

2 Estland, Latvia, Litauen, Polen, Slovakia, Slovenia, Tsjekkia og Ungarn ble EU-medlemmer i 2004, mens Bulgaria og Romania kom med i 2007. I 2013 ble også Kroatia medlem. 
Flere studier har dokumentert at mobile arbeidstakere, og i særlig grad utsendte arbeidstakere, har større risiko enn andre for dårlige forhold når det gjelder helse, miljø og sikkerhet, så vel som andre arbeidsvilkår (Friberg \& Eldring 2013, Eldring et al. 2011). Disse arbeidstakerne er ofte sysselsatt i næringer som i utgangspunktet har en større risiko for avvik fra gjeldende regelverk og standarder, som for eksempel i byggenæringen og transportsektoren. Dette innebærer at det er et stort behov for tilsyn og kontroll med utenlandske virksomheter som utfører oppdrag i nordiske land. Samtidig byr tilsyn med og myndighetsutøvelse overfor utenlandske bedrifter med utsendte arbeidstakere, også kalt utstasjonering, på helt særegne utfordringer.

I dette prosjektet ser vi derfor nærmere på arbeidstilsynenes rolle og utfordringer $\mathrm{i}$ arbeidet rettet mot utenlandske virksomheter og arbeidstakere i Danmark, Norge og Sverige. Helt konkret har vi undersøkt hvordan tilsynene gjennomfører kontroll, tilsyn og veiledning innenfor bygge- og transportnæringen.

Hovedvekten har vært lagt på hvordan tilsynene faktisk arbeider og løser oppgavene innenfor dette krevende feltet, mer enn på forskjeller i overordnet regelverk.

De mest sentrale problemstillingene i prosjektet har vært:

- Hva slags oversikt har arbeidstilsynene over utenlandske bedrifter og hvordan etablerer de denne oversikten?

- Hvordan fungerer ulike registerordninger og krav om id/HMS-kort?

- Hvilke prioriteringer gjøres av arbeidstilsynene? Hvordan velges bedrifter/byggeplasser ut for tilsyn? Hva er omfanget av tilsyn rettet mot slike virksomheter?

- Hvordan takles språkproblemene?

- Brukes det særegne metoder og verktøy i tilsynene som er rettet mot utenlandske bedrifter? Og er det behov for nytt regelverk og/eller verktøy?

- Samarbeides det med andre tilsyns- og kontrolletater? (eksempelvis skatteetat, politi, mattilsyn).

- Samarbeides det over de nordiske landegrensene? Eventuelt hvordan, eller hvorfor ikke?

- Hva fungerer bra og mindre bra i de ulike landene? Hva kan man lære ("best practice")? 


\subsection{Metode og data}

Arbeidstilsynene i Danmark, Norge og Sverige har vært våre samarbeidspartnere i prosjektet, og har bidratt med informasjon og kunnskap gjennom hele prosjektperioden, samt tilrettelegging av feltbesøk. Datainnsamlingen har foregått gjennom to arbeidsmøter med representanter fra partnerne, en rekke kvalitative intervjuer i de tre landene, samt feltarbeid.

Det første arbeidsmøtet med representantene fra de tre arbeidstilsynene ble brukt til å diskutere problemstillinger og erfaringer, og å planlegge den videre datainnsamlingen i prosjektet. I prosjektets andre fase ble det gjennomført feltbesøk i hvert av landene. Feltarbeidet foregikk på den måten at vi som forskere var med inspektører fra arbeidstilsynene ut på tilsyn i to dager i hvert land. Det ble ikke satt av spesielle ressurser til å ta seg av forskerne i felt, vi fulgte med inspektørene som "fluer på veggen". Intervjuer og feltarbeid ble gjennomført vår og høst 2015. I hvert av landene ble det også intervjuet sentrale og ansvarlige aktører for dette området i de nasjonale arbeidstilsynene. I Sverige intervjuet vi også representanter fra Byggnads på lokalt og sentralt nivå. Hvert intervju varte i 1-2 timer.

På det andre arbeidsmøtet fikk deltakerne anledning til å diskutere funnene fra datainnsamlingen og gi kommentarer og innspill til den endelige rapporteringen.

Prosjektets utgangspunkt var å studere tilsyn med utstasjonering det vil si utenlandske virksomheter med egne arbeidstakere på oppdrag $\mathrm{i}$ et annet land. I praksis ble det en studie av tilsyn med "utenlandske arbeidstakere", uavhengig av om de er utstasjonerte eller ikke. Den viktigste grunnen til dette er at tilsynene ofte er uanmeldte og/eller basert på tips. Det innebærer at inspektørene kjører rundt til virksomhetene for å se hva som foregår. Da kan det avdekkes om det faktisk er utstasjonering på arbeidsstedet eller om de utenlandske arbeidstakerne er fast eller midlertidig ansatt i en norsk, svensk eller dansk virksomhet. Tilsynene gjennomføres uavhengig av tilknytningsformen for arbeidstakerne.

I rapporten bruker vi som regel det norske ordet "arbeidstilsyn" når vi omtaler arbeidstilsynene i de tre landene samlet. Når vi spesifikt skriver om Danmark, Sverige eller Norge, bruker vi de nasjonale betegnelsene, henholdsvis Arbejdstilsynet, Arbetsmiljöverket og Arbeidstilsynet.

I rapporteringen er det laget egne tekstbokser hvor vi forteller fra feltarbeidet. Disse kan stå som illustrasjoner på hvordan inspeksjonene gjennomføres. 



\section{Bakgrunn}

I pilotprosjektet "Arbeidstilsynenes roller, strategier og redskaper i arbeidet mot sosial dumping: En nordisk pilotstudie" (Eldring et al. 2013) ble det foretatt en første kartlegging av de nordiske arbeidstilsynenes rolle, strategier og redskaper i arbeidet mot "sosial dumping".

Selv om utfordringene er sammenlignbare, og til dels det overordnete regelverket, er det store variasjoner i hvordan disse utfordringene håndteres i den praktiske tilsynsvirksomheten. Til og med terminologien er forskjellig. I Norge og Danmark er begrepet "sosial dumping" velkjent, mens det nesten ikke brukes i Sverige. Her anvendes i stedet betegnelsen "grå bedrifter", og nylig (fra 2016) "usunn konkurranse". Begreper som arbeidslivskriminalitet, anstendig arbeid, ordnede forhold og useriøsitet er også blitt mer vanlig i Norge og Danmark.

Sosial dumping er ofte definert som uakseptabelt lave lønninger og dårlige arbeidsvilkår. Men, det er ikke et entydig begrep. Hva som regnes som uakseptabelt, og dermed som sosial dumping, vil variere mellom ulike land, mellom ulike bransjer, mellom arbeidslivets aktører og også av politisk ståsted (Eldring et al. 2013).

\section{$2.1 \quad$ Ulike sjekkpunkter}

Overvåking av helse-, miljø- og sikkerhet på arbeidsplassene er hovedoppgaven i alle landene. I Norge føres det også tilsyn med lønn der det er allmenngjorte tariffavtaler. I Danmark har Arbejdstilsynet fătt oppdraget med å sjekke at utenlandske virksomheter registrerer/anmelder seg i RUT (Registret for udenlandske tjenesteydere). ${ }^{3}$ Felles for de tre landene er at arbeidstilsynet er underlagt arbeidsdepartementene, med en utenforliggende sentral enhet/direktorat som igjen har regionenheter.

EUs regelverk krever at kontroll-, registrerings- og håndhevingstiltak må ha en klar, ikke-diskriminerende lovhjemmel. Gitt at alle de nordiske landene er medlemmer av ILO og EU/EøS, har de

\footnotetext{
3 På dansk brukes betegnelsen "anmelde" om registreringen i RUT. Siden ordet "anmelde" har en litt annen valør på norsk, bruker vi i fortsettelsen ordet registrering også når det gjelder RUT.
} 
forholdsvis lik lovgivning for arbeidstilsynene, spesielt når det gjelder helse og sikkerhet (Eldring et al. 2013).

Når det gjelder lovfestede krav til minstelønnsstandarder og myndighetenes rolle, er det store forskjeller internt i Norden, noe som har betydning for tilsynsmyndighetenes mandat på dette punktet.

Danmark og Sverige bruker tariffavtaler som eneste mekanisme til å regulere minstelønn, og er slik sett unike også i europeisk sammenheng. De faglige organisasjonene inngår overenskomster (tiltredelsesoverenskomster/hengeavtaler) også med utenforstående arbeidsgivere, og har en vid adgang til å benytte arbeidskonflikter, herunder sympatiaksjoner, for å få tegnet tariffavtale (Kristiansen et al. 2015).

\subsection{Allmenngjøring av tariffavtaler}

I Norge er flere av bransjene som har rekruttert mange arbeidsinnvandrere nå omfattet av en allmenngjort tariffavtale. Allmenngjøring innebærer at den tariffavtalte minstelønnens (og eventuelt andre tariffbestemmelser) dekningsområde utvides, slik at den gjelder for alle i en hel region, bransje og/eller yrke uavhengig av om arbeidsgiver og/eller arbeidstaker er organisert. Så langt er følgende bransjer omfattet av en allmenngjort tariffavtale: bygg, skips- og verftsindustri, landbruk, renhold, elektrofag, fiskeindustri, godstransport og turbil.

\subsection{Nye utfordringer - nye tiltak}

I både Danmark, Sverige og Norge har arbeidsinnvandringen og tjenestemobiliteten $\varnothing \mathrm{kt}$ kraftig etter østutvidelsene i EU (Eldring \& Friberg 2013). Dette har utløst en rekke responser fra myndighetene, særlig i Danmark og Norge. I begge landene fikk tilsynene i en periode tildelt mer ressurser for å håndtere de økte utfordringene $\mathrm{i}$ en del bransjer, og har spilt en viktig rolle når det gjelder gjennomføringen av tiltaksplaner og initiativ mot sosial dumping.

I Danmark kom temaet høyere på dagsorden i 2012, da det ble politisk enighet om styrket innsats for å bekjempe sosial dumping. 4 I de påfølgende årene er det gitt særlige bevilgninger til tilsyn mot sosial dumping. Finansloven for 2016 viderefører dette, med prioriteringer av midler til koordinert myndighetsinnsats mellom Arbejdstilsynet, Skat og

${ }^{4}$ Finansministeriet (2011), Aftaler om Finansloven for 2012. November 2011. 
Politiet, styrket innsats når det gjelder kontroll av utenlandske virksomheter og styrking av RUT. ${ }^{5}$ Det danske Arbejdstilsynet er delt i tre regioner, med hvert sitt tilsynssenter. I tilknytning til hver av disse er det etablert såkalte "task force" som har et særskilt ansvar for aksjoner rettet mot utenlandske virksomheter. ${ }^{6}$

I Norge lanserte Stoltenberg-regjeringen sin første handlingsplan mot sosial dumping i 2006, som senere ble fulgt opp med en andre handlingsplan i 2008 og en tredje i 2013. Handlingsplanene inneholdt en rekke tiltak, som spente fra lov- og forskriftsendringer, betydelig økning av ressurser til tilsyns- og kontrollvirksomhet, og til informasjons- og veiledningstiltak (Eldring et al. 2011). I januar 2015 presenterte Solbergregjeringen en ny strategi mot arbeidslivskriminalitet. ${ }^{7}$ Her blir flere av tiltakene fra de tidligere handlingsplanene fulgt opp, og det legges dessuten svært stor vekt på samarbeidet mellom offentlige etater som et sentralt virkemiddel mot arbeidslivskriminalitet.

I Sverige har problematikken inngått i Arbetsmiljöverkets satsningsområde "grå økonomi", men det har i mindre grad enn de andre landene vært eksplisitt søkelys på sosial dumping i forbindelse med utenlandske virksomheter og utstasjonerte arbeidstakere. I en prosjektrapport fra Arbetsmiljöverket om arbeidet med utenlandske foretak og arbeidstakere sies det at:

"Allmänt sett har frågan om utländska företag og arbetstagare problematiserats. Ett övergripande problem er är att dessa ofte kopplats sammen med problem avseende säkerhet, villkor och löner. Detta ger en missvisande definition av vad som är det verkliga problemet. Enligt AV:s uppfatning är det i stället de företag som varken vill eller kan skapa en bra arbetsmiljö eller ett bra arbetsliv, den så kallade "grå sektorn", som är det verkliga problemet. Dette oavsett om företagen är utländska eller inte" (Arbetsmiljöverket 2012:5, side 9).

Det svenske Arbetsmiljöverket har dermed ikke fătt like klare oppdrag når det gjelder tilsyn med utenlandske virksomheter og sosial dumping som tilsynene Danmark og Norge, og det er heller ikke bevilget ekstra penger til kontroll med virksomheter og arbeidstakere fra de nyeste EU-landene.

\footnotetext{
${ }^{5}$ Aftale mellem regeringen, Dansk Folkeparti, Liberal Alliance og Det Konservative Folkeparti: Finansloven for 2016 (19. november 2015).

${ }^{6}$ Arbejdstilsynet, Skat, Politi, Afrapportering af myndighetsinnsatsen mod social dumping 2012-2014. April 2015.

7https://www.regjeringen.no/contentassets/4f7ae70171bd480682b8dafddadaf311/strategi_mot_arbeidslivskriminalitet.pdf
} 
Arbetsmiljöverket har fra 2016 startet et nytt prosjekt til erstatning for "grå økonomi". Det kalles "Osund konkurrens i arbetslivet", og skal i første omgang vare i tre år. En viktig del av prosjektet er samarbeid mellom ulike myndighetsorganer. Hvordan det skal føres tilsyn med utenlandske virksomheter og hvilke bransjer som peker seg ut, er to forhold som skal diskuteres videre framover.

\subsection{Utstasjonering og håndhevelse}

I mai 2014 ble det vedtatt et EU-direktiv (2014/67/EU) som på norsk omtales som håndhevingsdirektivet. Dette skal implementeres i medlemslandene innen sommeren 2016, og er relevant i denne sammenhengen fordi det åpner for nye tiltak og verktøy for nasjonale myndigheters tilsyn og kontroll med utenlandske virksomheter og deres ansatte. Siden fristen for den nasjonale implementeringen ennå ikke er gått ut, gir vi her bare en kort oversikt over de viktigste punktene i direktivet.

Formålet med håndhevingsdirektivet $\mathrm{er}$ å forbedre håndhevelsene av reglene i utstasjoneringsdirektivet (96/71/EF). Utstasjoneringsdirektivet har blant annet som formål å sikre utstasjonerte/utsendte arbeidstakere de samme grunnleggende lønns- og arbeidsvilkår som arbeidstakerne i vertslandet (altså det landet de reiser til for å arbeide).

Ett av problemene med utstasjoneringsdirektivet har vært fiktive utstasjoneringer. Det vil si at arbeidsgivere har konstruert utstasjoneringsoppdrag gjennom postboksselskap for å omgå krav til lønns- og arbeidsvilkår i vertslandene. Derfor inneholder håndhevingsdirektivet en rekke momenter for å vurdere om utstasjoneringen er reell. Det dreier seg blant annet om å undersøke om virksomheten har aktivitet i landet hvor de utstasjonerte sendes fra, eller om det kun er snakk om administrative oppgaver. Det skal også vurderes om arbeidet uføres i en begrenset periode, hvor gjentagende utstasjoneringen er, og om arbeidsgiver betaler utgifter til reise, kost og losji.

Håndhevingsdirektivet fastsetter hvilke kontrolltiltak medlemsstatene kan gjennomføre. Det kan dreie seg om rett til å kreve informasjon fra virksomheten om antall utstasjonerte arbeidstakere, oppdragets varighet og hvilke arbeidsoppgaver som skal utføres. Det åpnes også for å kreve at virksomhetene har arbeidskontrakter, lønnsslipper og timelister tilgjengelig. At det utpekes en kontaktperson for virksomheten i det landet hvor arbeidet utføres, er også en mulighet. Denne personen skal kunne representere virksomheten i spørsmål knyttet til tariffavtaler. EU/EøS-landene kan iverksette andre tiltak enn dem som er uttrykkelig nevnt i direktivet. 
Direktivet legger også opp til at statene kan innføre et solidaransvar for lønn i kontraktskjedene (artikkel 12). I byggebransjen skal det innføres solidaransvar eller annen hensiktsmessig ordning som ivaretar hensynene som begrunner bestemmelsen. Ansvaret kan begrenses dersom oppdragsgiveren kan vise til at det er satt i gang tiltak for å sikre seg at oppdragstakeren betaler sine arbeidstakere i henhold til vertslandets regler.

Det stilles videre krav til hvilken bistand myndigheter skal yte til hverandre over landegrensene, og hvor raskt dette skal skje. Dette dreier seg om informasjon, kontroller, tilsyn og etterforskning. Andre lands myndigheter kan bistå med informasjon i forbindelse med inndrivelsen av bøter ilagt i vertslandet. Informasjon om lønns- og arbeidsvilkår i vertslandet skal være allment tilgjengelig på internett - også hvilke tariffavtaler som kommer til anvendelse.

\subsection{Registreringsordninger}

Ett stort problem, ikke bare i Norden, men innenfor hele EU/EØS-området, har vært en mangelfull oversikt og registrering av utenlandske bedrifter (inkludert deres ansatte) som utfører midlertidige oppdrag på tvers av landegrensene. Dette har bidratt til dårlig oversikt over det faktiske omfanget av arbeidskraftmobiliteten i Europa, siden statistiske oversikter ofte kun har inkludert individuelle arbeidsinnvandrere (Dølvik \& Eldring 2008, Friberg \& Eldring 2013). Viktigst i vår sammenheng er det at disse bedriftene lettere har kommet "under radaren", rett og slett fordi de ikke er behørig registrert i landene hvor tjenestene utøves. For arbeidstilsynene byr dette på særskilte utfordringer, ikke minst fordi erfaringen er at behovet for tilsyn og kontroll er ekstra stort når det gjelder disse virksomhetene. I det følgende skal vi se nærmere på hva slags registreringsordninger som finnes per i dag i Danmark, Norge og Sverige.

\section{Danmark}

Utenlandske virksomheter med utstasjonerte arbeidstakere og utenlandske selvstendig næringsdrivende har siden 2008 hatt plikt til å registrere seg i det såkalte RUT-registeret. ${ }^{8}$ Det er den danske

${ }^{8}$ Dette avsnittet bygger delvis på kapittelet "Det danske RUT-register" i rapporten "Europa og den nordiske Aftalemodel", TemaNord 2015:537 
utstasjoneringsloven (kapittel 3) som regulerer dette registeret. Registreringen foregår kun elektronisk.

Virksomhetene skal melde inn navn og adresse, og dato for levering av tjenesteytelsen. I tillegg kreves det opplysninger om arbeidssteder, kontaktperson, bransjekode (og eventuelt momskode i utlandet). Når det gjelder arbeidstakerne, må virksomheten melde inn navn, statsborgerskap, fødselsdato samt start- og sluttdato for utstasjoneringen. Registreringen må skje seinest samtidig med at arbeidet i Danmark er påbegynt. Endringer i en eksisterende registrering skal registreres senest den førstkommende hverdag etter at endringen har trådt i kraft. Den utenlandske virksomheten mottar en elektronisk kvittering som dokumentasjon for at registreringen er gjennomført.

I bransjene bygg og anlegg, rengjøring, landbruk, skogbruk og gartneri har bestilleren (oppdragsgiver) medansvar for at oppdraget registreres i RUT. Internasjonal transport skal også registreres i RUT, men ikke kabotasjekjøring. ${ }^{9}$ Danske virksomheter registrerer seg i Det centrale virksomhedsregister (CVR).

Unntatt fra registreringsplikten er deltakelse i seminarer og konferanser, artister og idrettsutøvere, forretningsreiser, regnskap og revisjon inntil åtte dager, kabotasjekjøring, virksomhetsintern utstasjonering inntil åtte dager (som ikke angår bygg og anlegg, landbruk, skogbruk og gartneri, rengjøring og hotell- og restaurantvirksomhet).

Dersom bedriftene ikke er registrert, eller mangelfullt registrert i RUT, kan Arbejdstilsynet sende en innstilling til politiet om tiltale, eller utstede administrative bøter (10 $000 \mathrm{DKK}$ ) - hvilket er den vanligste reaksjonsformen.

Arbejdstilsynet har hovedansvaret for kontrollen, og bruker registeret som utgangspunkt for sine tilsyn (se mer om dette i neste kapittel). Skattemyndighetene får tilgang til registeret i forbindelse med sine kontroller. Tilsvarende adgang har andre myndigheter.

Mange av opplysningene i RUT er offentlig tilgjengelige. Det gjelder for eksempel arbeidssted.

I perioden fra 2012 til og med 3. kvartal 2015 ble det sendt inn 1050 tiltaleinnstillinger for manglende eller mangelfull registrering i RUT, og

\footnotetext{
${ }^{9}$ Kabotasjekjøring er transport mellom steder inne i et annet EU/EØS- land enn der transportøren er registrert. Lovlig kabotasje kan bare utføres den første uka etter at den internasjonale transporten er avsluttet, og det er ikke lov til å utføre mer enn tre slike transportoppdrag før lastebilen må krysse grensen igjen. Kabotasjeoppdragene kan heller ikke være av permanent eller løpende karakter (Jensen et al. 2014).
} 
utstedt 609 administrative bøter. Statistikken viser at om lag en tredjedel av bøtene var vedtatt og betalt. ${ }^{10}$

\section{Norge}

I Norge skal utenlandske virksomheter og arbeidstakere registreres hos Sentralskattekontoret for utenlandssaker (SFU). I tillegg må alle som skal drive virksomhet i Norge ha et organisasjonsnummer, som fås ved å registrere seg i Enhetsregisteret (ett av Brønnøysundregistrene). Oppdragsgiver har opplysningsplikt om oppdragstaker og om de arbeidstakere som benyttes for å utføre oppdraget. Oppdragstaker har også opplysningsplikt om de arbeidstakere vedkommende benytter for å utføre oppdraget.

Opplysningsplikten framgår av ligningsloven § 6-10 med forskrift. Det skal gis informasjon om kontraktspartene, oppdragets start- og sluttdato samt stedet der oppdraget utføres. Dersom det oppstår endringer, skal det sendes en endringsmelding. Ved rapportering av arbeidstakere skal det blant annet gis informasjon om hvem som er arbeidsgiver og hvilket oppdrag arbeidstaker er tilknyttet. Rapporteringen av arbeidstakere skjer i to omganger; når arbeidstakeren starter på oppdraget og ved avslutning.

Det skal fylles ut et skjema som kan sendes inn elektronisk. Dersom opplysninger mangler, kan skattemyndighetene ilegge løpende dagmulkt inntil opplysningene blir gitt.

Inspektører i det norske arbeidstilsynet har ikke direkte tilgang til registeret. Det er heller ingen opplysninger som er offentlig tilgjengelige. Arbeidstilsynet savner oversikt over utstasjoneringsbedrifter og har uttrykt ønske om et register som likner på det danske RUT. I forbindelse med den nasjonale implementeringen av håndhevingsdirektivet heter det fra departementet at en slik ordning krever ytterligere utredninger. ${ }^{11}$

\section{Sverige}

Sverige innførte i 2013 en registreringsplikt for utenlandske virksomheter med utstasjonerte arbeidstakere i Sverige. Det overgripende målet med registeret er å sikre at utstasjonerte arbeidstakere omfattes av de rettigheter som følger av utstasjoneringsdirektivet. Den utenlandske virksomheten skal melde inn

${ }^{10}$ Arbejdstilsynet, Skat, Politi, Afrapportering af myndighetsinnsatsen mod social dumping 2012 - 3. kvartal 2015. November 2015.

${ }^{11}$ Høring om gjennomføring av håndhevingsdirektivet i norsk rett. Abeids- og sosialdepartementet 13. januar 2016. 
arbeidssted, arbeidstakere og kontaktperson til Arbetsmiljöverket før oppdraget begynner. Utstasjonering i inntil fem dager behøver ikke meldes. Overtredelse av bestemmelsen kan straffes med en bot på 20000 SEK. Opplysninger om arbeidsgiver, arbeidssted, oppdragsgiver og bransje er offentlig tilgjengelig. Arbetsmiljöverket har som oppdrag å utvikle og forvalte registeret, samt å utøve tilsyn med at bestemmelsene om registreringsplikt og kontaktperson følges. Tilsynet har også en svartjeneste som hjelper med spørsmål om utstasjonering og om nødvendig gir hjelp til registrering.

På Arbetsmiljöverkets nettside publiseres månedlig statistikk over utstasjoneringer. I snitt var det registrert drøyt 6500 utstasjonerte i Sverige hver måned i perioden januar 2014 til juni 2015. Polakker utgjorde den største gruppa, deretter følger utstasjonerte fra Tyskland, India og Litauen. Majoriteten arbeidet innenfor bygg- og anlegg, men det var også en betydelig andel innenfor datavirksomhet. ${ }^{12}$

Arbetsmiljöverket bruker ikke registeret som utgangspunkt for tilsyn (slik som i Danmark), men skal i prinsippet sjekke om utstasjoneringsbedriftene de fører tilsyn med er registrert. Inspektørene kan sende inn forespørsel til registeret om hvorvidt registrering er foretatt, men videre oppfølging foregår sentralt. Inspektørene har imidlertid ikke myndighet til å spørre etter legitimasjon, noe som kan gjøre det vanskelig å sjekke om arbeidstakerne er registrert. Det utstedes ikke noe bevis på registreringen. En av inspektørene vi intervjuet sa det slik: Hvordan skal vi sjekke ting? Det er ingen vi kan ringe til. Vi fär ikke lov å be om legitimasjon en gang. Det er det politiet som må gjøre.

Registeret gir mulighet til å få informasjon om hvor utstasjonering foregår, og også arbeidstakerorganisasjonene har tilgang til disse opplysningene, og kan eventuelt følge opp om de utstasjonerte har tariffmessige vilkår. På lokalt og sentralt nivå i fagforbundet Byggnads ble det imidlertid gitt uttrykk for at det er grunn til å tro at det er stort antall utstasjonerte som ikke er meldt inn i registeret.

12 Arbetsmiljöverket (2015), Halvårsrapport - register för företag som utstationerar arbetstagare i Sverige 1 januari - 30 juni 2015. Rapport 2015:14. 


\section{Tilsyn: metodikk og erfaringer}

\subsection{Hva slags oversikt har arbeidstilsynene over utenlandske bedrifter/arbeidstakere?}

Alle landene har en form for registreringsplikt av utenlandske virksomheter/arbeidstakere, men det er variasjon når det gjelder hvordan dette gjøres, om opplysningene er offentlig tilgjengelige og hvordan de brukes i praksis (se kapittel 2).

Det er bare Danmark som systematisk besøker virksomheter registrert i registeret for utenlandske tjenesteytere (RUT), og bruker det som utgangspunkt for utvelgelsen av tilsynsbesøk. Alle virksomheter får som utgangspunkt tilsyn senest 14 dager (dog avhengig av lengden på tjenesteytelsen) etter at de er registrert dersom de tilhører bransjer hvor det etter Arbejdstilsynets erfaring er mange arbeidsmiljøproblemer. ${ }^{13}$ Det dreier seg for eksempel om bygge- og anleggsbransjen. Virksomheten kan bruke det samme RUT-nummeret dersom den har flere oppdrag i Danmark samtidig, eller over tid.

I Sverige brukes ikke registeret på denne måten. Det undersøkes ikke hvilke utenlandske virksomheter som er registrert $f ø r$ inspektørene drar ut på tilsyn, og det foregår heller ikke noen systematisk sjekk av utstasjoneringsregisteret i forbindelse med ordinære tilsyn.

13 Tidligere var praksisen at alle RUT-virksomhetene fikk besøk fire ganger. Erfaringen var imidlertid at i visse bransjer er det ikke flere problemer enn blant tilsvarende danske virksomheter. Våren 2015 ble det derfor innført risikobasert tilsyn, hvilket innebærer at det nå gjennomføres stikkprøvetilsyn. Virksomheter med arbeidsmiljøproblemer får gjentatte besøk, inntil det er gjennomført ett besøk uten anmerkninger. Deretter fredes virksomheten for en periode. 
I Norge har ikke Arbeidstilsynet tilgang til oversikten over utenlandske virksomheter som er innmeldt til Sentralskattekontoret for utenlandssaker. Inspektørene kan kontakte SFU for spørsmål om en utenlandsk virksomhet er registrert, samt hvor mange og hvilke arbeidstakere som er registrert. Dette gjøres som oftest etter et tilsyn. Arbeidet baseres dermed i hovedsak på ulike former for oppsøkende virksomhet, uten kunnskap om virksomheten er utenlandsk eller ikke. I tillegg kommer det inn en del tips, hvor det kan framgå om det er en utenlandsk virksomhet eller ikke. Det norske arbeidstilsynet ønsker derfor å få et eget utstasjoneringsregister, etter mønster av RUT. De viktigste begrunnelsene er å få vite hvor virksomhetene befinner seg og kunne håndheve regelverket mer effektivt, inkludert manglende registrering.

Erfaringene fra Danmark de siste årene tilsier at en del utenlandske virksomheter registrerer seg i Det centrale virksomhedsregister (CVR), altså som et dansk selskap, for å utføre oppdrag i Danmark. Dette kan være en måte å unngå RUT-registrering - og kontroller - på. Det er derfor opprettet et eget prosjekt som går ut på å identifisere disse virksomhetene. Det har blitt større oppmerksomhet rundt danske virksomheter med mange utenlandske arbeidstakere. Det trekkes derfor lister fra CVR ut fra spesifiserte kriterier (for eksempel mange pendlere). Listene danner så utgangspunktet for tilsyn. Det er Arbejdstilsynet som samkjører virksomhetsregistrene og lager listene.

I Norge diskuteres også mulighetene for å etablere et eget kabotasjeregister. Dette er blitt aktualisert i forbindelse med allmenngjøring av godstransport og turbiltrafikk. Allmenngjøringsforskriften vil kun gjelde for arbeid utført i Norge, og derfor er det avgjørende å vite når bilene kjører inn og ut av landet. 
Figur 1: Skjema som brukes av det danske Arbejdstilsynet i forbindelse med RUT-kontroller

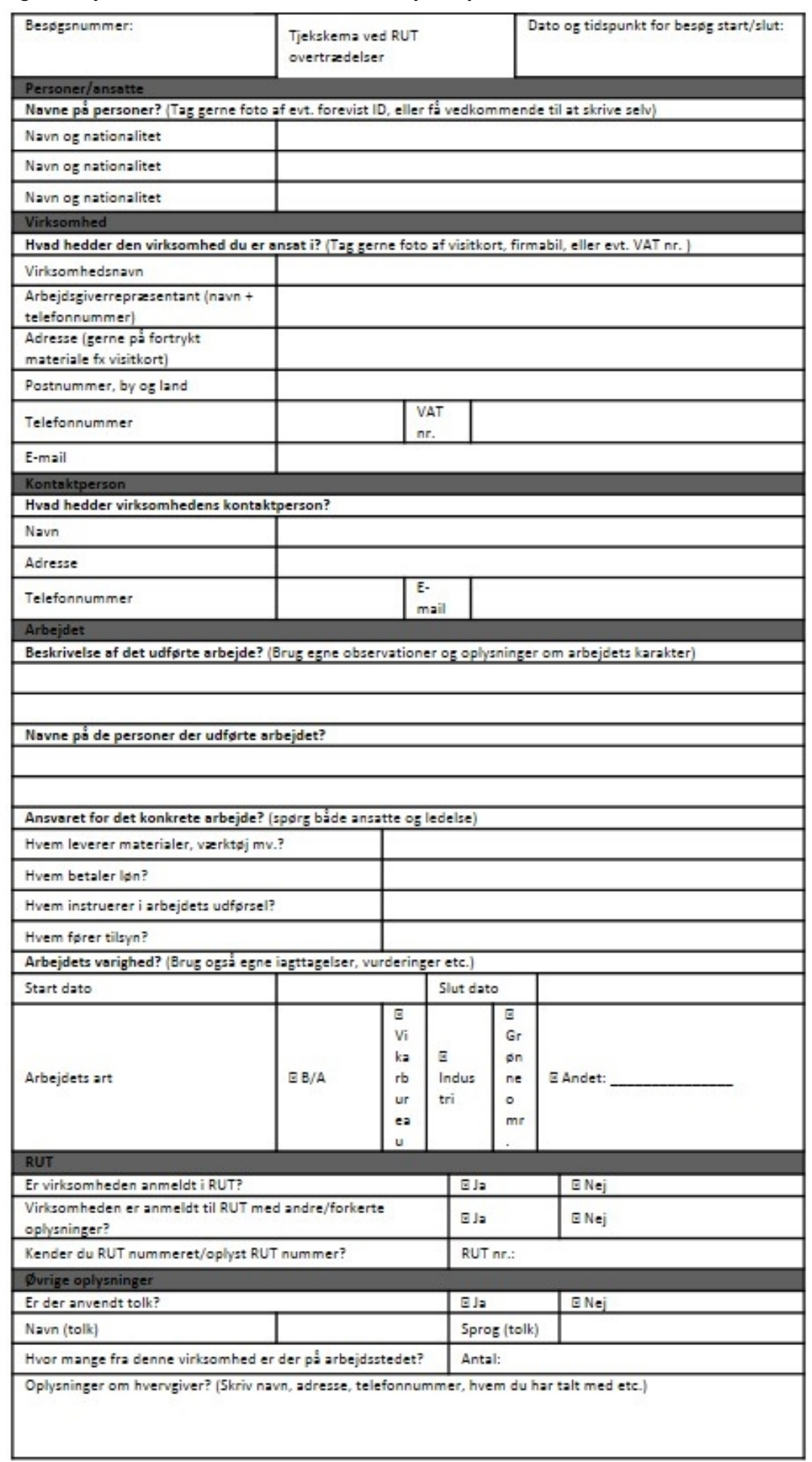




\subsection{Organisering og gjennomføring av tilsynsvirksomheten}

I alle landene er det slik at tilsynene planlegges og giennomføres på flere ulike måter. Utgangspunktet for tilsyn kan være registrering (RUT), kjennskap til lokale arbeidsmarkeder og risikovurderinger, byggemeldinger og tips fra utenforstående. Et fellestrekk for de tre landene er at inspektørene fører tilsyn med helse, miljø og sikkerhet på arbeidsplassene, eksempelvis sikring av arbeid i høyden, riktig bruk av verneutstyr, godkjente sertifikater og garderobeforhold. Når det gjelder etterarbeid og oppfølging, er det variasjoner mellom landene i hvordan dette gjøres.

\section{Egne "sosial dumping"-tilsyn i Danmark og Norge}

Arbeidstilsynene i Danmark og Norge har egne "sosial dumping"-tilsyn som er rettet mot utenlandske virksomheter og arbeidstakere i såkalte utsatte bransjer. Men, utenlandske virksomheter kontrolleres også i forbindelse med tilsyn som i hovedsak har mer generelle arbeidsmiljøutfordringer som hovedtema. Det kan for eksempel være i situasjoner hvor man går bredt ut, eller dersom inspektørene kjører rundt for å se etter aktivitet (gjelder spesielt byggebransjen).

Både i Danmark og Norge er det inspektører som har spesialisert seg på tilsyn med utenlandske virksomheter/arbeidstakere, i tillegg til å ha særegen kunnskap om utvalgte bransjer. På såkalte "sosial dumping"-tilsyn er det vanlig at to inspektører er sammen på tilsyn. Som regel er dette begrunnet både i sikkerhet for inspektørene og for å sikre god kommunikasjon. Det vil si at man får anledning til å snakke med både ledere og arbeidstakere ute på arbeidsplassene, i tillegg til å gjennomføre kontroller av sikkerhet og arbeidsmiljø. Disse tilsynene er i all hovedsak uanmeldte.

I Sverige er det ingen egne tilsyn rettet spesielt mot utenlandske virksomheter/arbeidstakere. Kontakt og kontroll med utenlandske virksomheter/arbeidsplasser tas som en del av den ordinære virksomheten, og de fleste besøk er meldt på forhånd. Det svenske prosjektet om "grå foretak" hadde ingen spesiell oppmerksomhet rundt utenlandske virksomheter. Dette er nå erstattet av et nytt prosjekt kalt "usunn konkurranse" (fra 2016), og det er ikke avklart hvordan utenlandske virksomheter/arbeidstakere skal håndteres inn i dette prosjektet.

De svenske inspektørene er knyttet til bransje - for eksempel bygg. Men ingen har særlig kompetanse når det gjelder utenlandske virksomheter/arbeidstakere. Her er det vanlig at inspektørene drar ut på egen hånd. 
Tilsynene til de danske inspektørene er i stor grad bestemt av hvilke virksomheter som kommer inn i RUT. Dette er naturlig, siden alle nye skal forsøkes besøkt innen 14 dager i relevante og risikoutsatte bransjer. Dersom en virksomhet får pålegg, blir også neste oppdrag gjenstand for tilsyn. Dersom alt er i orden, så er virksomheten "fredet" i ett år, hvor den ikke automatisk får tilsyn.

Det kommer også inn en rekke tips. Alle tips, som inneholder tilstrekkelig informasjon, skal i Danmark følges opp i løpet av få dager, og de aller fleste tips blir fulgt opp. Mange uregistrerte virksomheter fanges opp på denne måten. Tipsene kommer primært fra fagforeninger, private personer og konkurrerende virksomheter, samt utenlandske arbeidstakere som føler seg dårlig behandlet.

\section{På oppdrag etter tips på Jylland}

De to danske inspektørene har fått tips fra noen på byggeplassen om utenlandske arbeidere som holder på med montering av en sklie. Vi kjører dit, og finner dem. Én person er oppe i en stålkonstruksjon (med klatreutstyr), én kjører truck, mens den tredje lesser/losser på trucken. Inspektørene hilser, forteller hvor de kommer fra og spør etter sertifikat til trucken. Føreren har kun et polsk sertifikat.

Inspektørene finner også ut at det brukes feil stropper for å sikre last, noe som påtales. Så får klatreren spørsmål om han har opplæring i klatring.

Arbeidstakerne forteller at de jobber for et tysk firma, men at sjefen ikke er til stede på grunn av tannverk. Sjefen skaffer materialer, verktøy og leder arbeidet. Inspektørene spør om de er ansatt, og de svarer at de alle har hvert sitt firma. De er med andre ord selvstendig næringsdrivende. Papirene ligger der de bor, 5 minutter unna. De sier papirene kan hentes, men inspektørene sier at vi kan følge med dit de bor. Det viser seg å være en moderne hytte, hvor det er god plass, rent og ordentlig. Arbeidstakerne er fra Polen, i alderen 30-40 år.

Ingen av dem har registrert firmaet sitt i RUT, og de sier at de ikke var klar over dette kravet. De finner fram firmadokumentasjon, kontrakter, id etc. Den ledende av de tre (klatreren) viser dem en webside hvor alle polske virksomheter er registrert. Han viser også fram bevis på opplæring som klatrer. På et tidspunkt ringer en av inspektørene en polsk tolk, som hjelper til med oversettelsen. De får påbud om å ordne stropper og beskjed om at de kan få en bot på grunn av manglende RUT-registrering. Det sies ikke noe om botens størrelse (10 000 kroner på hver, og de spør heller ikke).

Hadde de tre polakkene vært ansatt, og ikke selvstendig næringsdrivende, ville det ha vært arbeidsgiver som hadde fått bot. 
Som nevnt brukes ikke det svenske registeret som utgangspunkt for tilsyn. Virksomhetene har heller ingen dokumentasjon på at de er registrert, som for eksempel kan vises til inspektørene ved tilsyn. Det er dermed ingen systematikk i inspektørenes bruk av det svenske registeret, og det ville heller ikke vært ressurser til å besøke alle virksomheter som registreres.

I Sverige må alle byggeprosjekter over en viss størrelse meldes, og inspektørene får kopi. Dette danner utgangspunkt for å vurdere hvor inspektørene skal dra på tilsyn. Videre kommer det inn tips som følges opp, og dette er et av de viktigste utvalgskriteriene for svenske inspektører. Men det er ingen frister for hvor raskt et tips skal følges opp, noe som kan føre til forsinkelser. For sein oppfølging kan føre til at byggeprosjektet er ferdig før inspektørene kommer ut. Det fryktes også at lang responstid fører til at allmennheten får redusert tillit til Arbetsmiljöverket.

\section{"Detektivvirksomhet"}

I Norge får inspektørene en viss oversikt som følge av forhåndsmeldinger av byggeprosjekter (i likhet med Sverige), som kan brukes som utgangspunkt i planlegging av tilsyn. Dersom arbeidet varer utover 30 virkedager eller overstiger 500 dagsverk, skal det sendes forhåndsmelding til Arbeidstilsynet. I tillegg kommer det inn en rekke tips. Mange av disse kommer fra utenlandske arbeidstakere som arbeider eller har arbeidet i virksomheter som ikke følger regelverket. Det kommer også tips fra regionale verneombud, arbeidslivets parter, andre etater og publikum. Det foregår også kartlegging og "etterretning" i samarbeid med andre myndigheter for å finne arbeidsplasser hvor det er behov for tilsyn. Denne typen "detektivvirksomhet" kan bli mer systematisert i forbindelse med at det nå skal etableres et tverretatlig etterretnings- og analysesenter i Norge.

I alle de tre landene driver inspektørene i bygg med oppsøkende virksomhet. Det typiske er at man kjører rundt for å se etter aktuelle byggeprosjekter som kan få tilsynsbesøk. Det ses da spesielt etter utenlandskregistrerte biler og andre tegn på utenlandsk arbeidskraft.

I Sverige og Danmark kan inspektørene også gå inn i privatboliger. Oppdragstakere hos private oppdragsgivere har plikt til å registrere seg $\mathrm{i}$ RUT, og det føres i Danmark tilsyn på linje med proff-markedet.

I Norge føres mange tilsyn i privatmarkedet, for eksempel i forbindelse med hyttebygging og ytre rehabilitering av bolighus (Andersen et al. 2014). Men Arbeidstilsynet går ikke inn i bebodde private hjem. Privatperson som bygger hus er ikke omfattet av byggherreforskriften. 


\section{Oppfølging og etterbehandling}

I Danmark har regionkontorene såkalte "back-office", som sjekker registreringer i RUT og som så kommuniserer nødvendig informasjon til inspektørene. Når inspektørene er ute på tilsyn, kan de ringe til "backoffice" for bistand. Disse saksbehandlerne er også delaktige i oppfølgingen i ettertid, sammen med inspektørene. De danske inspektørene har med andre ord en mer rendyrket inspektørrolle, sammenliknet med de svenske og norske. I Norge og Sverige er det inspektørene selv som har ansvar for oppfølgingen og saksbehandlingen i ettertid, og ofte med bistand fra jurister.

I Norge er det innført et saksbehandlingssystem (Betzy) som gjør at den enkelte inspektør kan søke på tilsyn på virksomheter i hele landet, og få opp navn på virksomhet/arbeidsgiver og hva sakene gjaldt. Dette gjør det enklere å følge opp virksomheter som driver i flere deler av landet. Betzy omfatter all aktivitet i tilsynet, ikke bare utenlandske virksomheter/arbeidstakere. I Danmark er det et tilsvarende system (ATIS) fra år 2000, hvor alle virksomhetsopplysninger, besøk og reaksjoner ligger. Alle i Arbejdstilsynet har tilgang til opplysningene i ATIS. I Sverige er det nylig innført et nytt system med bærbare datamaskiner ute på inspeksjon (Ines). Inspektørene sender også informasjon til juridisk avdeling i Arbetsmiljöverket.

I Danmark er alle inspektørene utstyrt med "tablets" når de er ute på tilsyn. Det innebærer at de lett kan slå opp i registrene. I tillegg kan de selv legge inn opplysninger, for eksempel at de har vært på besøk hos virksomheten. Dermed ligger all relevant informasjon til enhver tid inne, tilgjengelig for de andre. Inspektørene i Sverige og Norge har ingen tilsvarende hjelpemidler.

Det er etablert call-sentre ved de danske tilsynskontorene, som tar imot og svarer på tips og henvendelser (både telefoniske og elektroniske), både fra "menigmann", berørte arbeidstakere og virksomheter. Mange inspektører har obligatoriske vakter på callsenteret (to-tre dager annenhver uke). Ellers har inspektørene i hovedsak hjemmekontor, når de da ikke er ute "på veien".

I Norge er det en generell svartjeneste på telefon og nett, som også svarer på engelsk. I tillegg er det etablert servicesentre for utenlandske arbeidstakere (samarbeid mellom arbeidstilsyn, politi og skatt) i Oslo, Bergen, Stavanger og Kirkenes.

Inspektørene i alle de tre landene kan avslutte (lukke) en tilsynssak. 


\section{Hva med tilsyn langs veien?}

I alle tre landene er det bare politiet/vegmyndighetene som kan stoppe biler på veiene. Arbeidstilsynene har ingen myndighet til det. Siden det så langt ikke er såkalte "sosial dumping"-tilsyn rettet mot transport, verken i Sverige eller Danmark, er det heller ikke laget strategier for hva slags prioriteringer som skal tas når det gjelder utenlandske virksomheter/arbeidstakere.

I Norge er utenlandske virksomheter/arbeidstakere i transport for alvor satt på dagsordenen, også i Arbeidstilsynet. Det er gjennomført såkalte prøvetilsyn, både for turbil og godstrafikk. Disse tilsynene skiller seg fra tilsyn i bygg ved at de gjennomføres i samarbeid med Statens Vegvesen (som kan stanse busser og biler på veien). Tilsynet med turbil ble gjennomført på steder der man visste det var mange busser. Også i framtida vil cruiseterminaler og typiske turiststeder være de viktigste områdene for tilsyn. Når det gjelder godstrafikken, vil framtidige tilsyn trolig gjennomføres både på vei, terminaler og kontrollstasjoner.

\subsection{Hva kontrolleres?}

Hva undersøker inspektørene i de tre landene under tilsyn med utenlandske virksomheter/arbeidstakere i henholdsvis bygg og transport? Hva legges det vekt på? Som vi allerede har vært inne på, så er det stor variasjon i innholdet i tilsynene. Fellestrekket er kontroll med arbeidsmiljøet. I tillegg fyller inspektørene en veilederrolle, først og fremst på arbeidsmiljøområdet, men også når det gjelder for eksempel registreringsordninger.

\section{HMS-kort og oversiktslister}

I Norge er det innenfor byggenæringen innført krav om id/HMS-kort (HMS-kort regnes ikke som id-kort) ${ }^{14}$ som inspektørene sjekker under tilsynene. Sammen med kravet om at det skal være oversiktslister på byggeplassene, får de oversikt over hvilke arbeidstakere som er på arbeidsplassen og hvem som er arbeidsgiver. Kortene forenkler arbeidet for inspektørene og bidrar til å avdekke useriøse aktører. Inspektørene kan ikke kreve å få se annen legitimasjon.

Heller ikke i Danmark og Sverige kan inspektørene kreve å få se godkjent legitimasjon. I fall det blir uoverensstemmelser på dette

${ }^{14}$ Id-kortene skiftet navn til HMS-kort for ikke å bli forvekslet med ordinære id-kort. 
området, må politiet tilkalles. I Sverige ble det fra 1. januar 2016 innført krav om personallister på alle byggeplasser, som Skatteverket skal kontrollere. Selv om dette først og fremst er et skattemessig tiltak, kan det også gjøre arbeidet lettere for Arbetsmiljöverket. Disse listene vil i praksis ha samme funksjon som de norske oversiktslistene.

\section{Arbeidsmiljø og sertifikater}

I Danmark kontrolleres det om virksomheten og tjenesteytelsen er riktig registrert (i RUT), i tillegg til sjekkpunkter på arbeidsmiljø: for eksempel bruk av tekniske hjelpemidler, sertifikater, sikkerhet ved utgravninger og arbeid i høyden, bruk av stoffer/materialer og ergonomi. Det er laget en egen sjekkliste (Besøgsrapport) for utenlandske virksomheter. Lønn og arbeidstid er ikke noe som de danske inspektørene kontrollerer. Men, ved mistanke om svært dårlige betingelser på disse områdene, kobler inspektørene av og til inn skatteetaten.

I Sverige føres det tilsyn med arbeidsmiljø og sikkerhet, pauserom og garderober. Dersom inspektørene støter på utenlandske arbeidstakere, spør de om disse er utstasjonerte. Opplysningene noteres og rapporteres inn i ettertid. Inspektørene har ingen myndighet til å tvinge arbeidstakerne til å gi fra seg opplysninger.

I Sverige ble det (under våre feltbesøk) ikke brukt skriftlige sjekkpunkter. Men, det var sikkerhet, utstyr og trivsel for og blant arbeidstakerne som var gjennomgående hovedtemaer. Lønn og arbeidstid er ikke noe som sjekkes i forbindelse med inspeksjonene.

\section{Lønn og arbeidstid sjekkes i Norge}

I Norge har en rekke tariffavtaler blitt allmenngjort som følge av en omfattende arbeids- og tjenesteinnvandring fra Sentral- og Øst-Europa. Arbeidstilsynet har ansvaret for å kontrollere om disse bestemmelsene følges. Dette fører til at Arbeidstilsynet må kontrollere lønn og ytelser i de allmenngjorte områdene, i tillegg til tilsyn med arbeidstid, arbeidsmiljø og sikkerhet. Det kan med andre ord dreie seg om svært omfattende tilsyn i de allmenngjorte områdene, noe som gjelder både for bygg og transport. I bygg er det lang erfaring med allmenngjorte tariffavtaler (fra 2007 i hele landet), mens forskriften er av ny dato i transport (godstransport gjeldende fra 1.7.15 og turbil fra 1.10.15).

Norske inspektører har gjennom flere år hatt et eget spørreskjema som er oversatt til en rekke språk (blant annet alle de østeuropeiske språkene) som deles ut til de utenlandske arbeidstakerne i bygg. Nedenfor vises 
skjemaet som norske inspektører ber de utenlandske arbeidstakerne fylle ut. Det bes om informasjon om arbeidsgiver, arbeidskontrakt, lønn og arbeidstid, overtidsbetaling, lønnsslipp, diettpenger, overnatting og arbeidstøy. Dette sikrer at man får direkte informasjon fra arbeidstakeren selv. I tillegg brukes opplysningene til å følge opp eventuelle brudd på bestemmelsene. På arbeidsmiljøområdet er det som oftest minimumsstandardene som sjekkes hos utenlandske virksomheter. Innenfor bygg er det å unngå farlig arbeid (for eksempel i høyden), verneutstyr og sertifikater, ${ }^{15}$ samt tilgang til spiserom og toaletter.

Det er utarbeidet egne skjemaer som brukes under fellesaksjoner med andre tilsynsmyndigheter. I forbindelse med slike aksjoner kreves det at hver enkel myndighet på forhånd har gjort klare prioriteringer av hva de vil undersøke.

\section{Annen metode i transport}

I transportsektoren føres det i Danmark tilsyn kun ved havner og terminaler, det vil si ikke på veien. Det er ingen egne "sosial dumping"tilsyn innenfor transportsektoren, men det er under planlegging. Unntaket her er tilsyn med utenlandske virksomheter i havnene. Det er primært skatt og politi som tar hånd om godstransporten, gjennom aksjoner ved grensene og på veien. Politiet undersøker om hviletiden er overholdt. Transport, herunder kabotasje, beskrives som et svært vanskelig område. Virksomheter som driver kabotasje er ikke pliktige til å registrere seg i RUT.

I Sverige dreier kontrollene i transportsektoren seg i hovedsak om trafikk- og lastesikkerhet. I tillegg er det inspektører som jevnlig er aktive i havnene. Det er heller ikke på dette området noen ekstra oppmerksomhet rundt utenlandske virksomheter/arbeidskraft. Om virksomhetene er registrert i utstasjoneringsdirektivet, kontrolleres ikke. Det er Transportstyrelsen som sjekker kjøre- og hviletid.

I Norge er det fra 2015 satt i gang et eget sosial dumping-prosjekt innenfor transport. Det er allmenngjort lønn og diettpenger som så langt er plukket ut som de viktigste tilsynsområdene. Under prøvetilsynene i transport i Norge i 2015, ble det imidlertid rettet spesiell oppmerksomhet mot sjåførenes overnattingstilbud.

15 Utenlandske virksomheter er i Norge unntatt fra kravet om systematisk HMS-arbeid og bedriftshelsetjeneste. 


\section{Boligforhold undersøkes i liten grad}

Boligforholdene for arbeidstakerne er likevel noe som undersøkes i mindre grad, og dette er felles for alle tre land. Unntaket er dersom det framkommer at arbeidstakerne bor på selve arbeidsplassen (byggeplassen/brakker i tilknytning til arbeidsstedet), og/eller andre tilfeller der arbeidsgiver er ansvarlig for innkvarteringen. Det stilles spørsmål til arbeidstakerne om boforholdene, og det gis informasjon om hva slags rettigheter man har.

I Danmark er det laget en folder om hvilke krav som stilles til innkvartering. Denne er oversatt til sju språk. I Norge har Arbeidstilsynet også etablert egne "innkvarteringstilsyn" sammen med brannvesenet og eventuelt plan- og bygningsetat i den aktuelle kommunen.

\section{Hvem er arbeidstaker?}

$\AA ̊$ finne ut hvem som er arbeidstakere og hvem som er selvstendig næringsdrivende, er en felles utfordring i de tre landene. Selv om dette er noe som gjøres på enkelte tilsyn, var det vårt inntrykk at dette er et vanskelig område, som i praksis undersøkes i begrenset omfang av inspektørene. På de tilsynene der vi deltok, ble skillet mellom arbeidstakere og selvstendig næringsdrivende ikke problematisert.

I Danmark skal i utgangspunktet en viktig del av tilsynet være å finne ut hvem som er reell arbeidsgiver i det konkrete arbeidet. Dersom det for eksempel tegner seg et bilde av at hovedentreprenør er arbeidsgiver og ikke en underentreprenør, så gis påleggene til hovedentreprenør. Fra midten av april 2015 sendes det automatisk en kopi til hovedentreprenør og byggherre om pålegg nedover i kontraktkjeden. Dette gjelder både for danske og utenlandske virksomheter. ${ }^{16}$ Ute på de tilsynene der vi var med, sammen med inspektørene, var det ikke særlig stor oppmerksomhet rundt hvem som var arbeidsgiver - altså om det forekom "falske" selvstendig næringsdrivende. Det ble med andre ord i praksis stilt fă spørsmål om ansettelsesforhold under disse tilsynene. ${ }^{17}$ Ifølge Arbejdstilsynet sentralt er dette noe det normalt brukes en del tid på hvis det skal avgis reaksjoner på arbeidsmiljøet, siden avklaring av arbeidsgiveransvaret er avgjørende for hvem reaksjonen skal sendes til. I tillegg ble det, under de tilsynene vi deltok på i Danmark, i liten grad undersøkt om arbeidstakerne som var på plassen faktisk var de som var

\footnotetext{
16 Også i Norge er det vanlig å gi pålegg knyttet til sikkerhet på byggeplassen til byggherre/hovedentreprenør i stedet for til hver enkelt underleverandør.

${ }^{17}$ Et kompliserende forhold er at det i Danmark er ulike definisjoner av arbeidsgiverfunksjonen i

henholdsvis RUT og i arbeidsmiljøloven.
} 
registrert. Det samme var erfaringen fra Sverige. I Norge er det, på grunn av HMS-kortene, lettere å få oversikt over hvem som faktisk er på arbeidsplassen. Men, dette er noe som gjøres ved enkelte tilsyn.

Arbeidstilsynet i Norge har laget en momentliste for saksbehandlerne i vurderingen av om det er et enkeltpersonforetak eller arbeidstakerforhold. Dette gjelder uavhengig av om virksomhetene er utenlandske. Punktene er listet opp i boksen nedenfor. Disse er i hovedsak de samme sjekkområdene som brukes i Danmark på dette området. Vurderingen tas også ofte i samråd med jurister, i etterkant av inspeksjonen.

\section{Følgende kriterier kan tale for at det foreligger et arbeidstakerforhold} (Norge):

- arbeidstakeren har plikt til å stille sin personlige arbeidskraft til rådighet og kan ikke bruke medhjelpere for egen regning

- arbeidstakeren har plikt til å underordne seg arbeidsgiverens ledelse og kontroll av arbeidet

- arbeidsgiveren stiller til rådighet arbeidsrom, maskiner, redskap, arbeidsmaterialer eller andre hjelpemidler som er nødvendige for arbeidets utførelse

- arbeidsgiveren bærer risikoen for arbeidsresultatet

- arbeidstakeren får vederlag i en eller annen form for lønn

- tilknytningsforholdet mellom partene har en noenlunde stabil karakter, og er oppsigelig med bestemte frister

- det arbeides hovedsakelig for en oppdragsgiver.

I Sverige er avhengighetsforholdet mellom oppdragsgiver og oppdragstaker sentralt. Sentrale kjennetegn for en arbeidstaker er at denne utfører arbeid av økonomisk verdi under en annens ledelse. Den som utfører arbeidet er i en underordnet stilling. Det finnes altså situasjoner der den som formelt opptrer som selvstendig næringsdrivende likevel er å betrakte som en arbeidstaker. Vurderingen må gjøres fra sak til sak, og omfatter - i likhet med det norske og danske regelverket - spørsmål om egne arbeidsredskap og lokaler, hvem som leder arbeidet, vederlag m.m. 


\section{Felles transportaksjon i Sverige}

Tema for inspeksjonen nord for Uddevalla var lastesikring. Kontrollen ble gjennomført i samarbeid mellom politiet (som hadde ansvaret), kemner, trygd, biltilsynet og Arbetsmiljöverket. Det gjennomføres to slike samarbeidskontroller i løpet av året i region Vest - én på veien og én i Gøteborg havn.

I informasjonsbrevet fra politiet til de andre etatene heter det: Tanken bakom denna kontrollform är, dels att varje myndighet tillför varandra kunskaper och värdefulla kontakter, vilket innebär ett stort effekt- och kompetenstillskott vid kontroller av personer och fordon, dels ger det viktiga synergieffekter när allmänheten ser myndigheter jobba tillsammans. Det är en stor tillgång om olika myndigheter kan samverka tillsammans utan allt för stora byråkratiska hinder.

Det var to politimenn på motorsykkel som geleidet aktuelle lastebiler inn på kontrollplassen. Det var spesiell interesse for lastbiler med "myk" sikring rundt lasten. Ellers var det alle slags typer, størrelser og last. Fra Arbetsmiljöverket deltok to inspektører. Den ene var ganske nyansatt og fremdeles med for å lære, men gjorde oppgaver selvstendig. Den andre hadde lang erfaring. Det er i tillegg fem inspektører som er innom transportsektoren av og til, men som også dekker andre bransjer.

Under kontrollen var det politiet som førte ordet og spurte etter sertifikat, og sjåførene måtte også blåse for å sjekke eventuell promille. Det ble videre bedt om kjørebevis for EU/EøS. Politiet sjekket dessuten kjøre- og hviletid for siste døgn. Dersom papirene ikke er i orden, stanser politiet transporten.

Det oppdages stadig flere makedonske sjåfører med bulgarske papirer. Teorien fra tilsynsmyndighetene er at dette er den desidert billigste arbeidskraften som er praktisk mulig innenfor EU/EØS. Arbetsmiljöverket har ikke mulighet til å undersøke om transporten er kabotasje eller mer regulær transport i Sverige.

Biltilsynet undersøkte bilen teknisk. Kemneren så etter utbetalte skatteregninger (hadde med data). Arbetsmiljöverket var med politi og biltilsyn for å sjekke lastesikring - både at utstyret var riktig, at det var kontrollert og at bilen var lastet på riktig måte.

Dersom lasteramper og anordninger for disse ikke var merket, altså blitt kontrollert siste år, kunne det føre til ganske høye bøter.

Inspektørene sjekket at sjåføren hadde tilgang til vernesko og ordentlige klær, og slo ellers av en prat med dem: det dreide seg om de trivdes i arbeidet, hvordan sjefen var og om de hadde noen kontakt med kollegene. Hadde de for eksempel møter for å diskutere arbeidsmiljøspørsmål? Denne runden var mindre aktuell for de selvstendige sjåførene (som det var en del av). Det var heller ikke så mye prat med de utenlandske sjåførene. Det var ingen virkemidler med hensyn til eventuelle språkproblemer. 
Det ble ikke rettet spesiell oppmerksomhet mot utenlandske sjåfører. Tonen var at "de er det ikke så mye vi får gjort med likevel" - dette var også gjennomgangsmelodien fra politiet. Bilene ble vinket inn uavhengig av nasjonalitetsskilt.

Arbetsmiljöverket skrev opp alle bilnumrene, slik at det var mulig å sjekke dersom man lurte på noe i etterkant, eller om det dukker opp nye saker på et seinere tidspunkt.

Det ble også stanset noen mindre varebiler, type snekkerfirmaer og rørleggere. Inspektørene fra Arbetsmiljöverket fortalte at de ved å snakke med slike sjåfører fikk innblikk i hvordan disse firmaene ble drevet, og om det var grunnlag for Arbetsmiljöverket å komme på besøk på et seinere tidspunkt. Dette gjaldt også transportfirmaer.

Inspektøren forteller at felles tilsyn er svært nyttig, ikke minst fordi man får kontakter med andre myndighetspersoner - et navn og et telefonnummer som gjør det lettere å ta kontakt ved behov, og "slippe å sitte i kø i sentralbordet".

Felleskontroller har en lang historikk i region Vest - de begynte så smått for 25 år siden. Det er ingen nasjonale aksjoner og ikke noe samarbeid over grensen (Norge ville ha vært det mest nærliggende for denne regionen).

Siden det norske arbeidstilsynet har så mange områder som skal sjekkes i de allmenngjorte områdene, er det vanskelig å få kontrollert alt i forbindelse med ett tilsyn. Det gjøres derfor som regel prioriteringer i forkant. Med andre ord, inspektørene bestemmer seg for hva som er de viktigste områdene ved akkurat dette tilsynet. 
Figur 2: Skjema som brukes av det norske Arbeidstilsynet ved tilsyn med utenlandske virksomheter

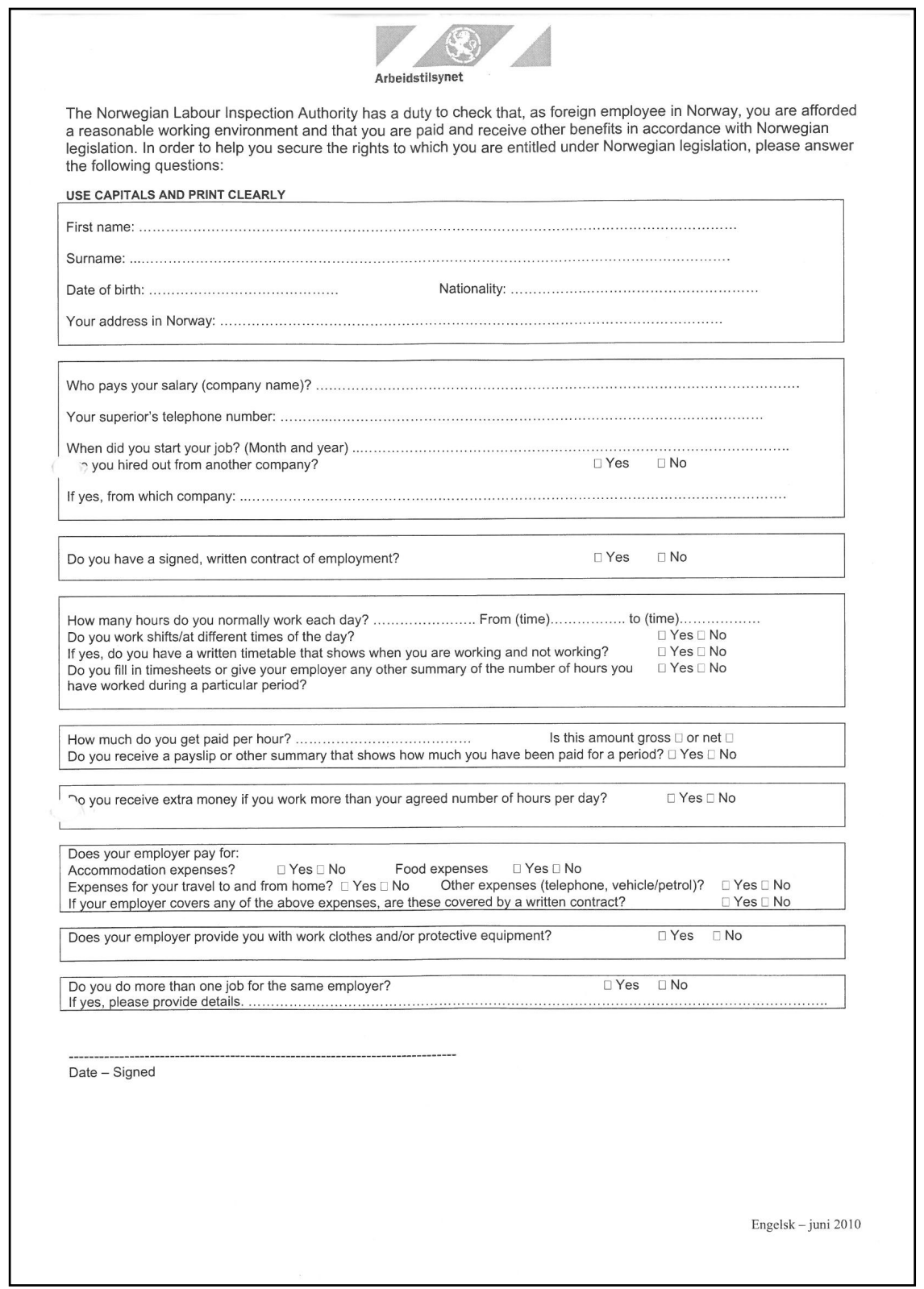

I transport er det utarbeidet egne skjemaer som er spesiallaget for bransjen, inspirert av de erfaringene som i en årrekke er gjort i bygg. Skjemaet som gjelder for turbil finnes så langt på seks språk. 


\section{Hvordan takles språkproblemene?}

I Norge har Arbeidstilsynet ansatt flere inspektører med utenlandsk bakgrunn, og med språkkompetanse på blant annet polsk, litauisk og russisk. I tillegg er diverse informasjon oversatt til ulike språk, samt at spørreskjemaer som utenlandske arbeidstakere skal svare på finnes på en rekke språk. Det er også mulig for inspektørene å kontakte tolker, men etter vår erfaring er dette noe som brukes i liten grad. Det er opp til den enkelte region å inngå avtaler med eventuelle tolketjenester. Arbeidstilsynet har også utarbeidet en egen brosjyre med informasjon til arbeidsgivere om krav til kommunikasjon og språk på bygge- og anleggsplasser.

I Danmark er det også ansatt inspektører med utenlandsk bakgrunn. Ellers har danske inspektører god tilgang på tolk via telefon og kan dessuten ta en tolk med på tilsyn, hvis det vurderes å være nødvendig. Dersom det oppstår problemer ute på en arbeidsplass, kan de danske inspektørene ringe tolketjenesten for simultantolking, og samtalen kan i de fleste tilfeller fortsette uten særlig opphold. Også her er flere foldere om sikkerhet på arbeidsplassen og RUT-registrering oversatt til engelsk, polsk, tysk og litauisk. Danske skjemaer/informasjonsmateriell er stort sett ikke oversatt til andre språk.

I Sverige er det utarbeidet brosjyrer på ulike språk, samt noen oversatte generelle setninger/spørsmål som kan tas med ut. Det er foreløpig ingen andre tiltak for å lette på språkutfordringene. Inspektørene må stole på egne kunnskaper, og noen uttrykker at det kan være vanskelig å kommunisere på engelsk.

Fra norsk side understrekes det at uten nødvendige språkferdigheter har det vært vanskelig å snakke med arbeidstakerne og oppnå den nødvendige tillit for å få fram gode opplysninger. Det er også problematisk å gi informasjon/veiledning om sikkerhet og verneutstyr, men her kan oversatte brosjyrer og foldere være til stor hjelp. For noen inspektører har språkproblemene representert en kjempeutfordring. Med mer erfaring, har dette blitt taklet på en bedre måte. Konklusjonen er likevel at det aller beste er å ha med inspektører som kan snakke med arbeidstakerne på deres eget språk.

\section{Sanksjoner}

I alle de tre landene kan arbeidstilsynene påby at forhold i strid med arbeidsmiljøloven raskt bringes i orden, eller innenfor en frist. Virksomhetene må melde tilbake om hva som er gjort, og risikerer uansett at tilsynet kommer tilbake for å sjekke. 
Ved overhengende fare kan tilsynet pålegge øyeblikkelig utbedring eller stanse arbeidet. Men inspektørene kan ikke stanse hele byggeplassen, kun det arbeidet som regnes som farlig.

Den danske finanslovsavtalen fra 2013 gir Arbejdstilsynet adgang til å utstede administrative bøter til utenlandske virksomheter som ikke er korrekt registrert i RUT. Første gangs overtredelse gir 10000 DKK i bot, neste gang er det 20000 kroner. Bøtene gis ikke på stedet. Det er juridiske avdelinger ved tilsynskontorene som tar seg av utstedelsen av bøter, ikke inspektørene.

I Sverige er det slik at inspektørene sender inn pålegg om sanksjonsavgift til juristen(e) i regionen. Hvis avgiften ikke godkjennes, går saken videre til forvaltningsretten og eventuelt til länsretten. Dersom det mangler dokumentasjon på maskiner som brukes i forbindelse med byggearbeidet, kan det føre til en avgift på SEK 40000.

I Norge kan arbeidet stanses dersom arbeidstakerne unnlater å følge Arbeidstilsynets pålegg om gyldige id-kort (HMS-kort) i bygg. I tillegg kan stansing av virksomheten brukes som pressmiddel for krav om utlevering av dokumentasjon på lønns- og arbeidsvilkår (arbeidskontrakter, lønnsslipper, timelister). Stansing som pressmiddel kan også mer unntaksvis brukes for å få gjennomført vesentlige pålegg, og der virksomheten ikke reagerer på pålegg eller tvangsmulkt. Arbeidstilsynet har fra 2014 hjemmel til å utstede overtredelesgebyr for brudd på arbeidsmiljøloven og allmenngjøringsloven. Gebyret kan maksimalt utgjøre om lag 1,3 millioner norske kroner (15 G - grunnbeløpet i folketrygden). For de alvorligste lovbruddene skal det fortsatt brukes politianmeldelse og ikke gebyr. Foreløpig er det gitt flest gebyrer for brudd på sikkerhetsbestemmelser. Overtredelsesgebyrer skal varsles, og det må fattes egne vedtak om disse.

Det kan være en stor utfordring å inndrive gebyrer/bøter fra utenlandske virksomheter. 
Tabell 1: Arbeidstilsynenes reaksjonskjeder i bygg

\begin{tabular}{lll}
\hline Danmark & Sverige & Norge \\
\hline $\begin{array}{l}\text { Brudd på Arbejdsmiljølovens eller dens } \\
\text { bekjentgjørelser: }\end{array}$ & Brudd på Arbetsmiljölagen med forskrifter: & $\begin{array}{l}\text { Brudd på allmenngjøringsloven og } \\
\text { arbeidsmiljøloven med forskrifter: }\end{array}$
\end{tabular}

Vanligvis frist på 3-6 måneder for å rette opp i påpekte forhold.

Virksomheten må sende en redegjørelse for hvordan problemet er løst.

Redegjørelsen skal vurderes av inspektøren som gjennomførte tilsynet, og som eventuelt gjennomfører kontrollbes $\varnothing$ k.
Vanligvis frist på 3 måneder for å rette opp i påpekte forhold. Om det ikke skjer, vedtak om pålegg, med varsel om administrativ bot om tiltak som må gjennomføres innen en viss tid. Sakene følges opp av inspektør og tilsynssjef/jurist. Dersom virksomheten ikke følger påleggene, går saken til jurist som vurderer om saken skal overlates ti domstolene. Det er domstolen som avgjør om den administrative boten skal betales.
Brudd på HMS-regelverket gir pålegg. Det normale er skriftlig varsel først, deretter pålegg med tidsfrist (varierer etter hvor faglig forholdene er og hvor enkelt de lar seg gjennomføre). Sakene lukkes når virksomheten kan dokumentere at påleggene er imøtekommet. Hvis påleggene ikke følges opp varsles og vedtas tvangsmulkt.

Krav om utlevering av dokumentasjon på Iønnsog arbeidsvilkår, med korte frister (3-7 dager). Det kan varsles stenging eller tvangsmulkt av virksomheten dersom kravet ikke følges opp. Hvis det framkommer at arbeidstakerne ikke avlønnes i henhold til de vilkårene som følger av forskriften om allmenngjøring, varsles pålegg.

Forbud med umiddelbar virkning, med varsel om administrativ bot, mot å fortsette virksomheten uten at vikårene er oppfylt. Dette gjelder særlig risikofylt arbeid, som arbeid $\mathrm{i}$ høyden uten beskyttelse mot fall. Forbud med umiddelbar virkning følges opp av inspektør i løpet av få dager.

Dersom det da fortsatt er virksomhet, går overtredelsen videre til tilsynssjef/jurist som vurderer om saken skal overlates til domstolene. Det er domstolen som avgjør om den administrative boten skal betales.

Arbetsmiljöverket kan vedta om et forbud skal ha umiddelbar virkning (se ovenfor), eller om det gjelder fra et visst tidspunkt. I begge tilfeller blir det varsel om administrativ bot dersom virksomheten ikke følger vedtaket. Dersom det har skjedd en arbeidsulykke med personskade, utredes hendelsen av inspektør og jurist, som siden melder videre til påtalemyndigheten. Slike hendelser reguleres ut fra en særlig strafferettslig lovgivning om

Ansatte må bringes ut av faresituasjonen og arbeidet kan ikke gjenopptas før det er fullt forsvarlig.

Utløser "grov overtredelse". Juristene vurdere administrativ bot. Kan ende med tiltale fra politie Virksomheten må sende en redegjørelse for hvordan problemet er løst.

Redegjørelsen skal vurderes av inspekt $\varnothing$ ren som giennomførte tilsynet, som eventuelt kan gjennomføre kontrollbes $\varnothing$ k. Det gjennomføres oftest et "skjerpet tilsyn" på samme arbejdsplass kort tid efter det først tilsynet.

\section{Administrative bøter}

Vedtas av juristene i Arbejdstilsynet før saken eventuelt går videre til politiet/domstolene. Bøter kan gis ved klare brudd og hvor saken ikke forventes å medføre høyere straff enn bøter. En betingelse er at det er en klar og fast rettspraksis for størrelsen på bøtene.

\section{Tvangsmulkt}

Det normale er å varsle tvangsmulkt etter at påleggsfristen har gått ut. Så vedtas tvangsmulkten etter frist satt i varselet.

\section{Stans}

Ved akutt fare for liv og helse kan Arbeidstilsynet stanse arbeidet på stedet. Arbeidet kan også stanses dersom arbeidstakerne unnlater å følge Arbeidstilsynets pålegg om f.eks. gyldige HMS-kort (id-kort). Stans kan også brukes som et pressmiddel til à få gjennomført pålegg.

\section{Sanksjonsavgift}

Vedtas av juristene i regionen ut fra den informasjonen som gis av inspektørene. Den kan ilegges for brudd på visse arbeidsmiljøbestemmelser og farlige situasjoner (for eksempel arbeid i høyden uten beskyttelse). Virksomheten kan godkjenne avgiften. Hvis ikke, kan domstolene bestemme at den skal betales.

\section{Overtredelsesgebyr}

Må varsles og det kreves eget vedtak.

I praksis vil overtredelsesgebyr forbeholdes alvorlige og/eller gjentatte brudd på arbeidsmiljølovgivningen. Om overtredelsesgebyr skal ilegges, og hvor stort gebyret skal være, bestemmes etter en konkret vurdering i den enkelte saken. Virksomhetene skal få et varsel og mulighet til å uttale seg $f \varnothing r$ vedtak fattes. 


\section{På kjøretur i innlands-Norge}

Den norske bygginspektøren har bestemt seg for å bruke dagen til å kjøre rundt og ser hvor det er aktivitet, og først og fremst se om han støter på utenlandske virksomheter. Det første stedet er oppføring av en seksmannsbolig på oppdrag fra kommunen. Her er det bare norske håndverkere. Forhåndsmelding skal henge på veggen i brakka, men det gjør det ikke. Inspektøren sjekker også HMS-perm og om arbeidstakerne har HMS-kort. Siden det ikke er utenlandske arbeidstakere til stede, spørres det ikke om lønn og arbeidstid.

Vi drar til flere steder hvor det bare er norske arbeidstakere. Inspektøren er spesielt opptatt av arbeid i høyden, fordi usikret arbeid kan føre til svært alvorlige ulykker.

Vi kommer til et boligfelt som er under utbygging. Ved det ene huset ser vi en utenlandskregistrert bil. Det er en enslig mann på byggeplassen, som viser seg å være fra Litauen, og han snakker verken norsk eller engelsk. Han forstår at Arbeidstilsynet vil se HMS-kortet hans. Det er i orden. Så får han et spørreskjema på litauisk, hvor han skal oppgi arbeidsgiver, lønn, arbeidstid m.m.. Da har han allerede ringt til en kollega eller sjef. Det framgår ikke klart hvem han ringer til. Han sitter og snakker i telefonen mens han fyller ut skjemaet. Inspektøren ber han om å legge på inntil han er ferdig med skjemaet, men han fortsetter å prate. Inspektøren må be han tre ganger om å legge på. Trolig får han noen beskjeder om hva han skal fylle ut. Arbeidstakeren har oppgitt at han tjener 200 kroner i timen. Dette er godt over minstesatsen, og inspektøren synes det er mistenkelig at han oppgir en så rund sum. Denne saken vil bli fulgt opp ved å be om skriftlig dokumentasjon fra arbeidsgiver - det vil si timelister og lønnsslipper. Dette gjør han regelmessig når han er i tvil om det gis riktige opplysninger. Heller ikke her er det forhåndsmelding og god nok HMS-informasjon oppslått i brakka.

Det er vanskelig å kommunisere med litaueren. Inspektøren forteller at de kan tilkalle tolk i tilfeller hvor det er absolutt nødvendig, men at det sjelden gjøres. Som regel klarer man å sjekke/gi enkle råd om sikkerheten på arbeidsstedet, pluss kontrollere HMS-kortet med lite språk.

Ved det neste huset er det en polsk arbeider som driver med takarbeid og en norsk lærling. Den ansvarlige har gått hjem for dagen. Den polske arbeideren er innleid hos underentreprenøren. Han snakker engelsk. Han har et HMS-kort som har gått ut på dato. Dette inndras av inspektøren, og arbeidstakeren får en kvittering på at kortet er inndratt. Ifølge den polske arbeidstakeren er nytt kort bestilt og på vei i posten. Han har vært i Norge i mange år, som innleid arbeidstaker, og har flyttet fra sted til sted. Han fyller ut skjemaet, som han får på polsk, og ingenting tyder på at det er noe feil med lønna. Det er for dårlig sikring på deler av arbeidsplassen. Men det er ikke akutt, siden det ikke foregår arbeid der akkurat nå. Lærlingen får instruksjoner i hvordan dette skal følges opp. Lærlingen får også utdelt en brosjyre om sikkerhet for unge arbeidstakere. 


\section{Samarbeid med andre offentlige etater}

I Norge er det de siste årene etablert et strukturert og mer systematisk samarbeid mellom flere etater (særlig Arbeidstilsynet, skattetaten, politiet og NAV). ${ }^{18}$ Formålet har vært å demme opp for arbeidsmiljøkriminalitet. De berørte direktørene møtes og blir enige om felles prioriteringer og rammer for samarbeidet.

Samarbeid skjer gjennom felles tilsyn, servicekontorene for utenlandske arbeidstakere og i sentre mot arbeidslivskriminalitet (Bergen, Oslo, Stavanger, Kristiansand og Trondheim). På disse sentrene sitter medarbeiderne sammen og samarbeider om analyse og etterretning, utfører felles kontroller og følger opp sakene på en samordnet måte. I tillegg til felleskontorene er det flere steder i landet etablert faste samarbeidsgrupper mellom etatene. Kemner deltar både på felles sentre og i samarbeidsgruppene. Hvilke ytterligere etater som deltar på felles sentre og i samarbeidsgruppene, vil variere etter bransje og sted.

Det gjennomføres også felles aksjoner med andre etater. Bygg og anlegg er den mest sentrale bransjen for dette samarbeidet, men det gjennomføres også tilsyn i servicebransjen (bilvask, frisør, restaurant, massasje og butikker). Alt etter bransje, deltar også etater som vegvesenet, kommunal skjenkebevilling, mattilsyn og brannetat. I Stavanger er det for eksempel regelmessig samarbeid med brannvesenet for å kontrollere dårlige/farlige boforhold. Etatene i Stavanger og Bergen har også hatt stor aktivitet rettet mot privatmarkedet for bygg og anlegg.

Et felles tilsyn starter gjerne med et tips eller at en av etatene har informasjon som tilsier felles innsats. Så blir det vurdert hvilke etater som skal være med, og hva slags regelverk som det er hensiktsmessig å bruke. Aksjonsuker brukes også som en felles arbeidsform. Det er nesten bare bygg som er omfattet av disse aksjonsukene. I 2015 har det vært flere aksjonsuker i flere regioner, delvis som følge av at dette er et prioritert område i regjeringens strategi mot arbeidslivskriminalitet (fra januar 2015). Det er samme logikk for fellesaksjonene over hele landet, men samtidig litt ulike modeller for samarbeidet. Arbeidstilsynet fungerer ofte som en døråpner fordi inspektørene er vant til å være ute i felten. De kjenner byggeplassene og har erfaring med å snakke med arbeidstakere og ledere for å få den informasjonen de ønsker.

I 2015 ble det gjennomført 12 større aksjoner, i hovedsak i bygg og anlegg, men også innen bilpleie og bilverksteder, samt serverings- og utelivsbransje. Aksjonene omfattet 1500 virksomheter.

${ }^{18}$ NAV er den norske arbeids- og velferdsetaten. 
De felles sentrene, hvor ulike etater er samlokalisert, har litt ulike sammensetninger. Saksbehandling og vedtak om å bruke virkemidler, samt kommunikasjon med virksomheten, skjer innenfor den enkelte etat.

Innenfor transport er det etablert en samarbeidsgruppe mellom Arbeidstilsynet, Vegdirektoratet, Tolletaten, Skatteetaten og politiet. Formålet er å utvikle et mer effektivt og formalisert samarbeid mellom ulike tilsynsetater, inkludert utvikling av en koordinert kontrollstrategi innenfor vegtransporten. Det legges opp til at et samarbeid vil omfatte alle typer kontroller, ikke bare kontroll av kabotasje.

Det er så langt gode erfaringer med samarbeidet mellom etatene. De viktigste positive virkningene er større treffsikkerhet, tilgang på mer ressurser og virkemiddelbruk (regelverk som kan benyttes). Taushetsplikten og informasjonsflyten har vært vanskelige områder, men beskrives ikke som et problem så lenge man samarbeider om konkrete saker. Erfaringen viser også at det er viktig at etatene setter av ressurser til å følge opp arbeid med saker som initieres i samarbeidet.

I Sverige er det lite samarbeid mellom den enkelte inspektør og andre myndigheter (for eksempel politiet) når det gjelder tilsyn med byggebransjen. Vårt inntrykk er at slikt samarbeid er spesialisert til andre deler av Arbetsmiljöverket. Dette til forskjell fra tilsyn i transport, hvor inspektørene regelmessig utfører tilsyn i samarbeid med politiet og andre offentlige etater, men da uten spesiell oppmerksomhet rundt utenlandske virksomheter/arbeidstakere. Det varierer hvem og hvor mange som deltar, men det kan være trygdemyndigheter, kemner og toll. Det er nedsatt en egen arbeidsgruppe som skal se på utfordringer knyttet til taushetsplikten. Det etterlyses også et system som ikke er personavhengig, men som kan være et effektivt verktøy for å dele informasjon.

Når danske inspektører er ute på "kjøretur", hender det at de samler inn informasjon om aktivitet på ulike byggeplasser, for siden å gjøre en større aksjon sammen med skattemyndigheter og politi. Når inspektørene er på tilsyn for seg selv, har de kontakter i politiet som de kan ringe til. Et slikt nettverk har de også med personer i skattemyndighetene.

Det danske Arbejdstilsynet fører som nevnt ikke tilsyn med arbeidstid, men hvis de mistenker alvorlige brudd, tas det kontakt med skattemyndighetene, som følger opp. Skatt kan for eksempel sjekke hvor mye arbeidstakerne har fătt i lønn. Arbejdstilsynet rapporterer også til skatt når en virksomhet ikke er registrert i RUT.

I perioden 2012-2014 gjennomførte de tre etatene (skatt, politi og arbeidstilsyn) 22 landsdekkende fellesaksjoner og 57 regionale. I samme periode besøkte arbeidstilsynet rundt 18400 arbeidssteder for å kontrollere utenlandske virksomheter, og det ble gjennomført 7300 tilsyn. Det ble gitt 
knapt 4000 reaksjoner, hvorav flertallet gjaldt ulykkesrisiko og krav til egeninnsats og lovpliktig utdannelse (for eksempel stillasutdannelse). Innsatsen i myndighetssamarbeidet har primært vært rettet mot bygg og anlegg, grønn sektor, hotell og restaurant og renhold. Det er videre etablert faste kontaktlinjer mellom etatene for å sikre et løpende samarbeid, og det avholdes jevnlige dialogmøter med arbeidsmarkedets parter.

Det utvikles personlige relasjoner mellom personene som deltar, noe som vurderes som svært verdifullt. Hver myndighet har taushetsplikt, men det sies at "vi finner alltid en vei" for å utveksle nødvendig informasjon. Bakgrunnen er nettopp de personlige relasjonene, tilliten og kunnskapen som opparbeides gjennom regelmessige treff. Det er Arbejdstilsynet som koordinerer samarbeidet mellom myndighetene.

\section{En første test av tilsyn med turistbusser, Norge}

Dette var den første gangen Arbeidstilsynet gjennomførte denne type tilsyn i transportbransjen, og er derfor omtalt som et prøvetilsyn.

Arbeidstilsynets to inspektører og Vegvesenet kjørte sammen. På grunn av mulige språkproblemer var også en medarbeider fra servicesenteret for utenlandske arbeidstakere (SUA) med på tilsynet, som snakker polsk, russisk og litauisk.

Vegvesenet spurte om alt av dokumenter, inkludert vognkort, løyve og tillatelser for bussen. Kjøre- og hviletid for de siste 15 dagene ble kontrollert. Arbeidstilsynets inspektører spurte om kontrakt og tok personinfo fra førerkort eller løyve, som allerede var framvist til Vegvesenet. Videre sjekket inspektøren navn, daglig leder, nasjonalitet, adresse, org.nr, ansettelsesform og -forhold for sjåføren, samt hvilket reiseselskap de kjørte for. I tillegg er det mer spesifikke kontrollpunkter om 1) skriftlig arbeidsavtale, 2) arbeidsplan som detaljerer arbeidstid, 3) registrering av all arbeidstid, 4) overtidstillegg, 5) forsvarlig innkvartering. De fleste sjåførene kan ikke framvise arbeidskontrakt på stedet, men det godtas hvis sjåførene sier at de har det.

Kontrollene ble gjennomført på steder der en visste at det ville være mange utenlandske busser. Utover sjekklisten, gikk også inspektøren gjennom hvor lenge de hadde vært i Norge, og hvilken rute de hadde. I tillegg til spørsmål om overnatting betalt av arbeidsgiver og om de noen gang sov i bussen, ble det sjekket om bussen hadde sovealkove.

En estisk sjåfør oppga at han alltid bodde på hotell, og mente at dette stort sett gjaldt alle estiske sjåfører. Han var på en 4-dagers tur til Vestlandet, fra Stockholm via Karlstad og Oslo. Det ble ikke framlagt dokumentasjon på overnatting, men sjåføren oppga blant annet navnet på et hotell. Inspektøren fant ikke grunn til å tvile på dette. På spørsmål om arbeidsplan oppga han at han 
hadde hatt to ukers sommerferie nylig, og hadde fått info om neste tur. Han fikk vanligvis vite planene for neste tur omtrent en uke i forveien, men det var uklart om det fantes noen skriftlig arbeidsplan. Det ble likevel ikke gitt noe pålegg for dette. Sjåføren oppga at det var vanskelig å få nok oppdrag om vinteren, men at han hadde en månedlig utbetaling fra arbeidsgiver uansett. Sjåføren var samarbeidsvillig og blid, inntil han ble spurt om hvor mye han tjente. Da ble han åpenbart litt stresset, og nektet å oppgi noe om lønna. Da allmenngjøringsvedtaket for buss ikke hadde trådt i kraft på dette tidspunktet, hadde ikke inspektørene i oppgave å kontrollere lønnsvilkår, og lot derfor være å forfølge temaet videre overfor vedkommende som ikke ønsket å oppgi lønn.

Arbeidstilsynet kan skrive til virksomheten og be om dokumentasjon, inkludert kontrakt og registrering av arbeidstid, noe som det ble vurdert å gjøre, selv om det er ressurskrevende.

En annen estisk sjåfør oppga at han kjørte 8 dager, og så bodde tre dager på Gardermoen. Papirer på bussen og logg for kjøre- og hviletid var i orden. Han hadde derimot ikke et system for timeregistrering/føring av arbeidstid, og oppga å ikke få betalt for overtid. Dette ga to pålegg. Det skrives da en tilsynsrapport, og den pluss påleggene sendes til det estiske firmaet sjåføren er ansatt i per post.

En polsk sjåfør fortalte at firmaet hadde arbeidsplaner og registrerte arbeidstid, men sa samtidig at han jobbet 10-11 timer daglig, hvorav 5-6 timer var kjøring. Han ble litt stressa da han ble spurt om lønn. Oppga å tjene 2900 zloty i måneden (ca. $6300 \mathrm{kr}$ ).

En annen polsk sjåfør snakket ikke engelsk, og den ansatte ved servicekontoret forsøkte derfor å oversette skjemaet til polsk. Det gikk på et vis, selv om det var litt uklart om alt ble forstått riktig. Sjåføren viste fram en arbeidskontrakt, men denne var på to setninger og framstod fullstendig useriøs - uten noe informasjon om hvilken lønn sjåføren hadde eller andre vilkår i jobben. Han oppga å jobbe 10-12 timer per dag, med alt fra 2 til 8 timers kjøring. Fikk ikke overtidsbetaling, og var uklar på hvor mye han egentlig hadde i lønn.

I etterkant av tilsynet skriver inspektørene tilsynsrapporter. Der skal tilsynet beskrives, påleggene begrunnes og standardformuleringer for pålegg og varsler endres, slik at det passer saken. Dette prøvetilsynet skal evalueres og brukes som grunnlag for videre tilsyn i bransjen. 



\section{Sammenfatning og vurderinger}

I årene etter at EU og EøS ble utvidet med nye medlemsland (2004 og 2007), har svært mange utenlandske arbeidstakere og virksomheter funnet veien til Norge, Sverige og Danmark. Den store tilstrømmingen har satt press på lønns- og arbeidsvilkårene i de nordiske landene. Risikoen for dårlige lønns- og arbeidsvilkår er høyere for arbeidstakere som er på korte opphold, er ansatt i utenlandske virksomheter, er ufaglærte, uorganiserte og tilknyttet på midlertidig basis.

Arbeidstilsynene spiller en sentral, men varierende rolle når det gjelder å sikre utenlandske arbeidstakere anstendige vilkår. Regelverk og rammebetingelser varierer mellom landene, noe som får følger for det praktiske arbeidet ute i felt. I dette prosjektet har formålet vært å undersøke hvordan inspektørene i tilsynene i de tre landene gjennomfører kontroll, tilsyn og veiledning med utenlandske arbeidstakere innenfor bygg og transport. Disse ble valgt fordi det er mange utenlandske virksomheter og arbeidstakere i bransjene, samt at det er felles grenseoverskridende utfordringer, ikke minst i transport.

I utgangspunktet skulle dette være en undersøkelse av tilsyn med utenlandske virksomheter og dere arbeidstakere - altså utstasjonerte virksomheter. I praksis ble det en studie av tilsyn med utenlandske arbeidstakere, uavhengig av om de var utstasjonerte eller ikke. Den viktigste grunnen er at tilsynene ofte er uanmeldte og/eller basert på tips. Tilknytningsform til arbeidsgiver blir eventuelt avklart ute på arbeidsplassene. I løpet av prosjektet viste det seg at det var begrenset erfaring med tilsyn med utenlandsk arbeidskraft i transportsektoren. Unntaket er såkalte prøvetilsyn med gods og turbil i Norge.

Det siste tiåret har bydd på krevende arbeidshverdager for inspektører både i Sverge, Danmark og Norge. Selv om utfordringene er felles, så er organisering, arbeidsmetoder og terminologi forskjellige.

Representanter fra arbeidstilsynene i de tre landene har vært våre samarbeidspartnere, og har bidratt med informasjon og kunnskap gjennom hele prosjektet. I feltarbeidet har hovedvekten blitt lagt på hvordan inspektørene faktisk arbeider og løser oppgavene. Vi har vært med på til sammen seks tilsyn fordelt på de tre landene. Dette er for få 
tilsyn til å dra generelle konklusjoner, men mange nok til å gi et innblikk i likheter og forskjeller i metoder og praksis.

Overvåkning av helse, miljø og sikkerhet (HMS) på arbeidsplassene er inspektørenes hovedoppgave i alle landene. I tillegg har inspektørene en veilederrolle, først og fremst på arbeidsmiljøområdet. I Norge føres det også tilsyn med lønn der det finnes en allmenngjort tariffavtale. Allmenngjøring innebærer at minstevilkårene i tariffavtalen utvides til å gjelde for alle i en region, bransje eller yrke, gjennom en forskrift. I Danmark har Arbejdstilsynet fătt oppdraget med å sjekke at utenlandske virksomheter registrerer/anmelder seg i RUT (Registret for udenlandske tjenesteydere).

$\AA$ A ha oversikt over utenlandske virksomheter og deres ansatte, som utfører oppdrag på tvers av landegrensene, er problematisk. Samtidig tilsier erfaringene at behovet for tilsyn og kontroll er ekstra stort når det gjelder denne typen mobile virksomheter. Danskene har løst dette gjennom sitt RUT-register, som kom i 2008. Virksomhetene skal melde inn navn og adresse, og dato for levering av tjenesteytelsen. I tillegg kreves det opplysninger om arbeidssteder, kontaktperson og bransjekode. Når det gjelder arbeidstakerne, må virksomheten melde inn navn, statsborgerskap, fødselsdato samt start- og sluttdato for utstasjoneringen. Arbejdstilsynet har ansvar for kontrollen av registreringen, og bruker denne som utgangspunkt for sine tilsyn. I Norge skal utenlandske virksomheter og arbeidstakere registreres hos Sentralskattekontoret for utenlandssaker (SFU). Arbeidstilsynet har ikke direkte tilgang til disse opplysningene, som heller ikke er offentlig tilgjengelige. Sverige har siden 2013 hatt en registreringsplikt for utenlandske virksomheter og utstasjonerte arbeidstakere. Utstasjoneringen skal meldes til Arbetsmiljöverket, som skal utvikle og forvalte registeret. Svenske inspektører bruker ikke registeret som utgangspunkt for tilsyn, men skal i prinsippet sjekke om de besøkte virksomhetene er registrert. Det er i utgangspunktet heller ikke ressurser til å besøke alle virksomheter som kommer inn i registeret.

I Danmark og Norge er det egne tilsyn, med spesialiserte inspektører, rettet mot utenlandske virksomheter og arbeidstakere. Slik er det ikke i Sverige. Tilsynene i Danmark er i hovedsak styrt av hvilke virksomheter som er registrert i RUT. De danske inspektørene har også en "back-office" med saksbehandlere som kan gi dem informasjon og bistand underveis i tilsynene.

Utgangspunktet for et tilsyn kan være registreringer (Danmark), kjennskap til og vurderinger av risikofaktorer i lokale arbeidsmarkeder, byggemeldinger og tips fra publikum eller andre virksomheter. Et annet fellestrekk er at inspektørene driver oppsøkende virksomhet, ved at de 
"kjører rundt" for å se etter aktuelle byggeprosjekter. I alle landene er det HMS-kontroller, som i bygg typisk vil være sikring av arbeid i høyden, bruk av verneutstyr, sertifikater og garderobeforhold.

I forbindelse med de spesialiserte tilsynene - også kalt "sosial dumping"-tilsyn - i Danmark og Norge, er det laget egne sjekklister og skjemaer. På grunn av at de danske inspeksjonene er knyttet til RUTregisteret, så er inspektørene utstyrt med "tablets" (nettbrett) for både å kunne slå opp og legge inn informasjon undergveis. I Sverige og Norge er det ingen tilsvarende virkemidler. I Norge er det innført krav om id/HMSkort for alle arbeidstakere på en byggeplass, noe som det er inspektørenes jobb å sjekke.

Lønn og arbeidstid er ikke noe inspektørene i Sverige og Danmark kontrollerer. I Norge er det Arbeidstilsynet som har ansvaret for å kontrollere arbeidstid, samt lønn i de allmenngjorte områdene. Det er utarbeidet et eget skjema på flere språk, der arbeidstakeren må fylle inn informasjon om arbeisdgiver, arbeidskontrakt, lønn, arbeidstid, overtidsbetaling, lønnsslipper, diettpenger, overnatting og arbeidstøy.

Språkproblemer er en utfordring for inspektørene i alle de tre landene. I Norge og Danmark har arbeidstilsynene ansatt inspektører med utenlandsk bakgrunn. I tillegg er diverse informasjon og spørreskjemaer oversatt til flere språk. Danske og svenske inspektører har også tilgjengelig informasjon oversatt til flere språk. I Danmark er det god tilgang til tolker via telefon når inspektørene er ute på tilsyn.

Sanksjonering - for eksempel inndriving av bøter - overfor utenlandske virksomheter kan være problematisk.

Det er varierende grad av samarbeid mellom inspektørene og andre offentlige etater, som for eksempel skatt og politi, i tilsynsarbeidet. Men alle erfaringer med slikt samarbeid og felles aksjoner er positive, og det uttrykkes ønske om at samarbeidet skal bli mer omfattende og systematisk. I Norge har det i løpet av det siste året kommet på plass et formelt og strukturert samarbeid mellom de offentlige etatene på dette området. Det er nå åpnet tverretatlige sentre mot arbeidslivskriminalitet i landets fem største byer.

Når det gjelder transportsektoren, ble det i alle landene uttrykt ønske om mer informasjonsutveksling og samarbeid mellom etatene, også på tvers av landegrensene, $i$ årene framover. 


\section{$4.1 \quad$ Vurdering}

Undersøkelsen viser at det er store variasjoner mellom de tre landene i hvordan tilsynsarbeidet organiseres, hva slags registreringsordninger som brukes, hva som kontrolleres og hvilken teknologi som er tilgjengelig. Arbeidet som inspektørene utfører er også knyttet til en personlig faktor. Tilsynene kan arte seg forskjellig, rett og slett fordi det er ulike personer som utfører dem, og er ikke nødvendigvis resultat av hva slags system man jobber under.

I dette avsluttende avsnittet vil vi se om det er mulig å utpeke en "best practice" ut fra de erfaringene vi har fătt kunnskap om i dette prosjektet. Hva fungerer bra og mindre bra i de ulike landene? Hva kan man lære av hverandre? Vurderingen vil ikke omfatte transportsektoren, da det er svært begrensede erfaringer med tilsyn med utenlandske arbeidstakere og virksomheter i den næringen (les om prøvetilsynet med turbil i Norge på side 33-34).

Språkbruken - altså terminologien - i de tre landene er talende og interessant. Den forteller både noe om hvordan utfordringene på dette området har blitt vurdert og hvordan det har blitt satset. I Danmark og Norge har begrepet "sosial dumping" blitt mye brukt gjennom en årrekke, og er også godt kjent i allmennheten. Inspektørene omtaler sitt eget arbeid som "sosial dumping"-tilsyn. Nå bruker den norske regjeringen begrepet "arbeidslivskriminalitet". I Danmark brukes begrepet "ordnede forhold" i stadig større grad, mens det i Sverige er brukt begreper som "grå bedrifter" og "usunn konkurranse". Språkbruken er i en viss grad knyttet til regjeringenes politiske farge til enhver tid.

Arbeidstilsynene i Danmark og Norge skiller seg klart ut, både ved å ha bedre utstyrte verktøykasser og mer systematiske tilsyn rettet mot utenlandske virksomheter og arbeidstakere. I disse to landene har det vært en bevisst og systematisk satsing i en årrekke. I Sverige har det ikke vært særlig oppmerksomhet rettet mot de særegne utfordringene for utenlandske virksomheter og arbeidstakere. Kontroll med disse har blitt tatt i forbindelse med ordinær virksomhet.

Det eneste fellestrekket mellom tilsynene i de tre landene er kontroll med helse, miljø og sikkerhet. Helt naturlig, siden dette er kjernevirksomheten for arbeidstilsynene. På dette området var det svært få forskjeller i hvordan tilsynene ble gjennomført og hvilken rolle inspektørene hadde som veiledere.

Registreringsordningene av utenlandske virksomheter og arbeidstakere i Sverige og Danmark har mange fellestrekk, men utnyttes 
på helt forskjellig måte. I Sverige kan man konkludere med at registeret ikke benyttes i det hele tatt som et verktøy for inspeksjoner.

I Danmark har registeret (RUT) vært styrende for tilsynsarbeidet. Det har vist seg å være et kraftfullt virkemiddel. Spørsmålet er heller om det har blitt for stor oppmerksomhet om registreringsordningen. Det vil si om den har skygget for utfordringer i virksomheter som ikke er pliktige til å registrere seg i RUT. Dette er også erkjent i det danske Arbejdstilsynet, som i den siste tiden har vridd tilsynene til å bli mer risikobaserte og mindre programmatiske. På tross av disse innvendingene, framstår RUT og bruken av registeret som et svært effektivt tiltak

I Danmark og Norge er det utviklet spesiell kompetanse på tilsyn med utenlandsk arbeidskraft. Det er egne inspektører som har dette som sitt område. Det gir større oversikt, kunnskap om vanskeligheter i forbindelse med selve tilsynene og trygghet, for eksempel når det gjelder å kommunisere på et annet språk (eller kun kommunisere ved hjelp av skriftlig materiale). I alle de tre landene er inspektørene knyttet til bransje, det vil si at de for eksempel har spesielt god kunnskap om eller erfaring fra bygg. Dette er trolig viktig for å gjennomføre tilfredsstillende inspeksjoner på HMS-området.

Inspektørenes hjelpemidler og støttefunksjoner er ulike. Den mest framtredende forskjellen er trolig nettbrettet som danske inspektører er utstyrt med. Dette gir dem direkte tilgang til registre og annen relevant informasjon mens de er ute på tilsyn. Her kan det også legges inn opplysninger med en gang. En annen god støttefunksjon for de danske inspektørene er tilgang til tolker via telefon. De danske inspektørene har dessuten saksbehandlere (back-office) som kan gi støtte mens de er ute på arbeidsplassene, samt at de har færre oppgaver i forbindelse med etterarbeid og oppfølging. Svenske og norske inspektører har ikke de samme teknologiske hjelpemidlene og utfører dessuten mer av saksbehandlingen selv, både før og etter tilsynene. Det vil si at den danske inspektørrollen er mer rendyrket enn i de andre landene.

Det norske HMS-kortet i bygg, som er påkrevd for alle arbeidstakere, er et tiltak som bør trekkes fram i positiv retning. Det gir inspektørene en rask oversikt over hvem arbeidstakeren og arbeidsgiveren er, hvilken nasjonalitet de har og hvor mange ulike virksomheter som er inne på arbeidsplassen.

Den norske ordningen med allmenngjøring av tariffavtaler har ført til at inspektørerene har fătt en rekke nye sjekkpunkter innenfor blant annet bygg. Arbeidstilsynet har ansvar for å undersøke at det ikke forekommer brudd på bestemmelser om lønn og ytelser, i tillegg til arbeidstid og HMSforholdene. Å se på helheten i arbeidsforholdet er trolig et effektivt virkemiddel for å unngå utnytting av utenlandske arbeidstakere. På den 
andre siden kan tilsyn i allmenngjorte områder bli svært omfattende. Ofte er det også nødvendig å følge opp undersøkelser av lønnsslipper og timelister, noe som fører til mye arbeid i ettertid.

Samarbeid og felles aksjoner mellom arbeidstilsynene og andre offentlige etater framstår som det mest effektive tiltaket for å bekjempe "sosial dumping" og "usunn konkurranse" i de nordiske arbeidsmarkedene, og bør videreutvikles. Dersom det er problemer med en virksomhet, så er de som regel sammensatte. Dårlige HMS-forhold og lav lønn henger ofte sammen med for eksempel skattejuks. Eksempelvis er det ifølge det danske Arbejdstilsynet påvist at utenlandske virksomheter som ikke er registrert i RUT, får markant flere arbeidsmiljøreaksjoner enn dem som er det. Flere etater sammen gir flere virkemidler (regelverk og sanksjoner), samt økte ressurser.

I denne sammenhengen er det verd å trekke fram de norske sentrene mot arbeidslivskriminalitet, som nå er etablert i fem byer. Her er medarbeidere fra sentrale etater (arbeidstilsyn, politi, trygd, skatt og toll) samlokalisert for å føre felles tilsyn, veiledning og kontroll mot utvalgte bransjer. Bakgrunnen er alvorlige og sammensatte problemer i deler av arbeidslivet, som trygdesvindel, hvitvasking og tvangsarbeid. Erfaringer viser at det er svært vanskelig å få løst slike saker uten et tett samarbeid mellom etatene.

Utfordringer med samarbeidet mellom offentlige etater er knyttet til taushetsplikt og informasjonsflyt mellom etatene. Samarbeidet er ofte avhengig av personlig kontakt mellom inspektørene i arbeidstilsynene og ansatte i eksempelvis skatteetat og politi. Årsaken er at det trengs både kunnskap og tillit for å løse problemene.

På tross av mange felles utfordringer er det nesten ikke noe praktisk samarbeid på tvers av landene. Det har dog vært en del erfaringsutveksling mellom de nordiske arbeidstilsynene de senere årene. Språklig og geografisk nærhet tilsier at det burde være mulig å samarbeide på enkelte områder, for eksempel informasjonsutveksling om virksomheter som opererer i flere land og erfaringer med ulike tilsynsmetoder. Arbeidslivsmodellene i Sverige, Danmark og Norge har såpass mange likhetstrekk at det ikke skulle by på større problemer å identifisere problemområder og dele erfaringer, selv om regelverk, verktøy og metodikk er forskjellig. Ikke minst fordi mangel på tid og ressurser er en felles utfordring i tilsynsarbeidet. 


\section{Referanser}

Andersen, R. K., L. Eldring \& J. R. Steen (2014) Privatmarkedet i byggenæringen. Usynlig arbeidsmarked i de tusen hjem. Fafo-rapport 2014:14

Arbetsmiljöverket (2012). Förstudie om det fortsatta arbetet med utländska företag och arbetstagare. Rapport 2012:5.

Dølvik, J. E. \& L. Eldring (2008). Arbeidsmobilitet fra de nye EU-landene til Nordenutviklingstrekk og konsekvenser. TemaNord 2008:502. København: Nordisk Ministerråd.

Dølvik, J. E., T. Fløtten, J. M. Hippe \& B. Jordfald (2014). Den nordiske modellen mot 2030. Et nytt kapittel? NordMod2030. Sluttrapport. Fafo-rapport 2014:46. http://dx.doi.org/10.6027/tn2008-502

Eldring, L., K. Ahlberg \& K. Pedersen (2013). Arbeidstilsynenes roller, strategier og redskaper $\mathrm{i}$ arbeidet mot sosial dumping: En nordisk pilotstudie. TemaNord 2013:523. København: Nordisk Ministerråd

Eldring, L. \& J. H. Friberg (2013). Europeisk arbeidsmobilitet: Utfordringer for de nordiske arbeidsmarkedene. Søkelys på arbeidslivet 30(1-2): 22-39

Eldring, L., A. M. Ødegård, R. K. Andersen, M. Bråten, K. Nergaard \& K. Alsos (2011). Evaluering av tiltak mot sosial dumping. Fafo-rapport 2011:09

Friberg, J.H. \& L. Eldring (ed.) (2013). Labour migrants from Central and Eastern Europe in the Nordic countries: Patterns of migration, working conditions and recruitment practices. TemaNord 2013:570.

Copenhagen: Nordic Council of Ministers.

Jensen R. S., M. Bråten, B. Jordfald, M. D. Leiren, T-O. Nævestad, K. H. Skollerud, H. Sternberg \& T. Tranvik (2014).

Arbeidsforhold i gods og turbil. Fafo-rapport 2014:58

Kristiansen, J., H. Tilly, L. M. Söderberg, F. Dreesen, M. Norðdahl, C. H. Johannessen, H. Stefánsdóttir, G. Sebardt, A. K. Lorentzen, J. Hellsten, J. Kragh \& E. Sjödin (2015). Europa og den nordiske Aftalemodel, TemaNord 2015:537.

http://dx.doi.org/10.6027/tn2015-537 



\section{Summary}

The Eastern enlargements of EU lifted borders between labour markets with huge differences in working and living conditons. This has spurred mobility of labour and companies from East to West in Europe. Many workers and companies from Central- and Eastern European countries have found their way to the Nordic countries, causing pressure on established standards in these labour markets. In this project we have studied how the labour inspectorates in Denmark, Norway and Sweden deal with foreign firms and workers within the construction and transport sector when it comes to inspections, monitoring and guidance on regulations. Although Denmark, Norway and Sweden are faced with similar challenges, there is considerable variation when it comes to measures and regulations that are put in place. There are also differences in how inspections are organised, in the requirements for registration of foreign companies and workers and in the technology that is available for the labour inspectors. 


\section{norden}

Nordisk ministerråd

Ved Stranden 18

DK-1061 København K

www.norden.org

\section{Nordiske arbeidstilsyn med utenlandsk arbeidskraft i bygg og transport}

Østutvidelsene av EU fjernet grensene mellom nasjonale arbeidsmarkeder med svært ulike nivåer i arbeids- og levekår, og har ført til stor mobilitet av arbeidskraft fra øst til vest i Europa. I dette prosjektet har vi studert hvordan arbeidstilsynene i Danmark, Norge og Sverige gjennomfører kontroll, tilsyn og veiledning av utenlandske virksomheter og arbeidstakere innenfor bygge- og transportnæringene. Selv om mange av utfordringene er felles, er det store variasjoner mellom landene når det gjelder hvilke tiltak og reguleringer som er iverksatt. Studien viser at det også er forskjeller i hvordan tilsynsarbeidet organiseres, hva slags registreringsordninger som brukes, hva som kontrolleres og hvilken teknologi som er tilgjengelig for tilsynsinspektørene. 